\title{
Alzheimer's Disease and Diabetes: Role of Diet, Microbiota and Inflammation in Preclinical Models
}

\author{
Maria Jose Carranza-Naval $1,2,3,+$, Maria Vargas-Soria $1,2,+$, Carmen Hierro-Bujalance ${ }^{1,2}$, Gloria Baena-Nieto ${ }^{2,4}$ \\ Monica Garcia-Alloza ${ }^{1,2}$ (D), Carmen Infante-Garcia ${ }^{1,2, *}$ and Angel del Marco ${ }^{1,2, * \mathbb{D}}$ \\ 1 Division of Physiology, School of Medicine, Universidad de Cadiz, 11003 Cadiz, Spain; \\ mariajosecarranza@uca.es (M.J.C.-N.); mariavargas@uca.es (M.V.-S.); carmenhierro@uca.es (C.H.-B.); \\ monica.garcia@uca.es (M.G.-A.) \\ 2 Instituto de Investigacion e Innovacion en Ciencias Biomedicas de la Provincia de Cadiz (INIBICA), \\ 11009 Cadiz, Spain; gbaenanieto@gmail.com \\ 3 Salus Infirmorum, Universidad de Cadiz, 11005 Cadiz, Spain \\ 4 Department of Endocrinology, Jerez Hospital, Jerez de la Frontera, 11407 Cadiz, Spain \\ * Correspondence: carmen.infante@gm.uca.es (C.I.-G.); angeljose.delmarco@gm.uca.es (A.d.M.) \\ + These authors contributed equally to this work.
}

\section{check for}

updates

Citation: Carranza-Naval, M.J.; Vargas-Soria, M.; Hierro-Bujalance, C.; Baena-Nieto, G.; Garcia-Alloza, M.; Infante-Garcia, C.; del Marco, A Alzheimer's Disease and Diabetes: Role of Diet, Microbiota and Inflammation in Preclinical Models. Biomolecules 2021, 11, 262. https:// doi.org/10.3390/biom11020262

Academic Editor: Marcus O.W. Grimm

Received: 29 November 2020

Accepted: 5 February 2021

Published: 10 February 2021

Publisher's Note: MDPI stays neutral with regard to jurisdictional claims in published maps and institutional affiliations.

Copyright: (c) 2021 by the authors. Licensee MDPI, Basel, Switzerland. This article is an open access article distributed under the terms and conditions of the Creative Commons Attribution (CC BY) license (https:/ / creativecommons.org/licenses/by/ $4.0 /)$.

\begin{abstract}
Alzheimer's disease (AD) is the most common cause of dementia. Epidemiological studies show the association between $\mathrm{AD}$ and type 2 diabetes (T2DM), although the mechanisms are not fully understood. Dietary habits and lifestyle, that are risk factors in both diseases, strongly modulate gut microbiota composition. Also, the brain-gut axis plays a relevant role in AD, diabetes and inflammation, through products of bacterial metabolism, like short-chain fatty acids. We provide a comprehensive review of current literature on the relation between dysbiosis, altered inflammatory cytokines profile and microglia in preclinical models of AD, T2DM and models that reproduce both diseases as commonly observed in the clinic. Increased proinflammatory cytokines, such as IL- $1 \beta$ and TNF- $\alpha$, are widely detected. Microbiome analysis shows alterations in Actinobacteria, Bacteroidetes or Firmicutes phyla, among others. Altered $\alpha$ - and $\beta$-diversity is observed in mice depending on genotype, gender and age; therefore, alterations in bacteria taxa highly depend on the models and approaches. We also review the use of pre- and probiotic supplements, that by favoring a healthy microbiome ameliorate AD and T2DM pathologies. Whereas extensive studies have been carried out, further research would be necessary to fully understand the relation between diet, microbiome and inflammation in AD and T2DM.
\end{abstract}

Keywords: Alzheimer's disease; type 2 diabetes mellitus; microbiota; diet; microglia; inflammation

\section{Alzheimer's Disease}

Growing life expectancy is secondarily contributing to a significant rise of pathologies associated with aging. Among them, dementias are specially relevant due to their prevalence, economical costs and societal burden [1]. Alzheimer's disease (AD) is the most prevalent form of dementia, which may contribute to $60-70 \%$ of total cases [2], followed by vascular dementia. AD neuropathological features include: amyloid pathology, neurofibrillary tangles and synaptic and neuronal loss [3]. Amyloid- $\beta$ peptide $(A \beta)$ can deposit as extracellular senile plaques (SP) or cerebral amyloid angiopathy (CAA) surrounding brain vessels. On the other hand, tau dysfunction includes hyper-phosphorylation and aggregation of tau-protein in paired helical filaments, the major constituent of neurofibrillary tangles, which can cause neuron loss in AD [4,5]. Neuronal loss is a later step in $\mathrm{AD}$ evolution and it is the pathological feature that best correlates with illness duration and severity [6,7]. Whereas the vast majority of the AD cases are sporadic and the causes unknown [8], neuropathological features and clinical phenotype are largely the same as in familiar AD cases. 
Apart from classical neuropathological features of $\mathrm{AD}$, other alterations have been described, and the concept of neurodegeneration has expanded to accommodate early alterations that include oxidative stress or inflammation [9]. Following this idea, neuroinflammation also plays a significant role in neurodegeneration [10]. In this sense, AD brains suffer neuroinflammatory changes including alterations in morphology and distribution of microglia and astrocytes, or increased expression of inflammatory mediators [11-13]. While microglia's response to injury is typically beneficial, it can go awry in cases of chronic injury and long-term inflammation, such as in AD. Thereby, microglia is chronically activated in the proximity of amyloid plaques and limits amyloid plaque growth [14] but, as the disease progresses, microglia fails to clear $A \beta$ from brain parenchyma and ultimately contributes to the neurodegenerative process $[13,15,16]$.

On the other hand, growing evidence has shown that alterations in the gut microbiota composition can alter normal brain function through the so-called gut-brain axis. Following this idea, the bidirectional communication between the central nervous system (CNS) and the gastrointestinal tract plays a key role in the pathogenesis of a variety of neuropsychiatric disorders and AD [17]. Moreover, regulation of gut microbiota has been implicated in the control of neuroinflammation and AD progression [18]. Additionally, in opposite direction, AD pathology could affect gut microbiota composition [17,19].

\section{Prediabetes and Type 2 Diabetes Mellitus}

Metabolic disorders include several pathologies. Among these, diabetes mellitus (DM) is one of the most prevalent diseases in the world. Moreover, type 2 diabetes (T2DM) is one of the leading causes of premature morbidity and mortality and its incidence increases with age $[20,21]$. The total number of people affected by DM is projected to rise up to 700 million in 2045 and about $90 \%$ of all the cases are of T2DM [22]. T2DM is characterized by an initial stage of insulin resistance or prediabetes, caused by the inability of the cells to fully respond to insulin, associated with blood glucose levels above the normal range but below the diabetes diagnostic threshold [23]. Currently, the most accepted position is that $\beta$-cell dysfunction, as impaired insulin secretion, is an independent abnormality that precedes dysglycemia, on a background of insulin resistance [24]. Although the development of this pathology shows high hereditability, T2DM seems to be caused by a combination of lifestyle and genetic factors [25]. In this sense, T2DM prevalence is increasing in children and younger adults, due to rising levels of obesity, sedentary lifestyle and inappropriate diet $[26,27]$.

Systemic inflammation also plays an important role in insulin resistance and the pathogenesis of T2DM. The disease is associated to a pro-inflammatory state with a moderate excess in the production of cytokines such as IL-6, IL-1 or tumor necrosis factor (TNF), which hinder the interaction of insulin with its receptor and contribute to insulin resistance and diabetes [28]. On the other hand, gut microbiota also seems to play a role in metabolic disorders including obesity, prediabetes and T2DM by influencing glucose homeostasis and insulin resistance, as well as by affecting digestion of sugars and production of gut hormones that control this process [29-32]. Nevertheless, the strict control of glucose levels in the gut is not only mediated by hormonal control but also by gut-brain axis control [33]. Moreover, gut dysbiosis may affect intestinal permeability, as well as the metabolism of carbohydrates and their products [34,35]. Following this idea, T2DM patients show gut microbial dysbiosis, including reduced abundance of some butyrate-producing bacteria or increased opportunistic pathogens [36]. The decrease of short-chain fatty acids (SCFAs) may ultimately contribute to insulin resistance [37], that can be reverted by SCFAs administration [38]. In this sense, the restoration of gut microbiota can improve metabolic alterations, which position pre- and probiotics as an interesting option to prevent and/or treat prediabetes and T2DM [31,39]. 


\section{AD-T2DM Relationship}

Previous epidemiological studies have shown that T2DM is strongly associated with cognitive impairment and late-onset AD [40-44]. Both pathologies, AD and T2DM, share several pathophysiological features $[45,46]$. Whereas implicated mechanisms have not been fully elucidated $[47,48]$ inflammation, diet or gut microbiota have been analyzed due to their possible role in the development of $\mathrm{AD}$, as presented below.

\subsection{Inflammation}

Microglia responds to pathogens and modulates the immune response in the CNS [49]. Although brain neuroinflammation is considered a relevant player in neurodegenerative diseases and $\mathrm{AD}[50,51]$ a cross-talk between peripheral and central inflammation has also been described [52]. The dual role of microglia in AD has been largely addressed [53,54] and whereas microglia may limit SP growth [14], uncontrolled chronic inflammation and release of neurotoxic factors, including inflammatory mediators and reactive oxygen species, result in the exacerbation of AD pathology [55-57]. While brain inflammation is a hallmark associated with neurodegeneration in $\mathrm{AD}$, peripheral blood inflammatory markers, such as IL-6, TNF- $\alpha$ or TGF- $\beta$ are detected in AD patients as well [58]. Additionally, systemic inflammation plays an important role in the pathogenesis of prediabetes and T2DM [59], given that the adipose tissue can overproduce pro-inflammatory cytokines like TNF- $\alpha$, which impairs insulin signalling, increasing the risk of insulin resistance [60]. Besides, TNF- $\alpha$ contributes to impair insulin signalling by increasing insulin receptor substrate-1 phosphorylation [61]. Altogether, it seems that T2DM, or even prediabetes, can cooperatively modulate the expression of brain pro-inflammatory cytokines in AD [12], and both the prediabetic state and T2DM, promote microglia activation in AD mice [62-64], supporting the role of the inflammatory process as a link between AD and T2DM.

\subsection{Diet}

Nutrition is considered a lifestyle factor that can modify the risk of dementia [65]. Nutrients reach the brain via the blood-brain barrier (BBB) by different mechanisms, such as facilitated diffusion or active transport [66]. Several studies have shown the role of specific nutrients, including folates and B12 vitamin, in brain volume loss in adult patients $[67,68]$. One of the most important effects of the diet is the ability to promote or control inflammation and therefore, neuroinflammation can be modified by a dietary pattern [69]. In this sense, Mediterranean diet (MD), considered an anti-inflammatory diet, is associated with preserved cognitive functions in elderly adults [70]. Ketogenic diet may improve neuropathological and biochemical changes associated to AD [71] as well as preserve cognition in patients with mild AD [72,73]. Likewise, studies in elderly patients have shown the neuroprotective effects of caloric restriction on memory [74].

On the other hand, T2DM onset can be improved by modifying lifestyle, including diet intervention [75]. Accordingly, healthy lifestyle with regular physical activity [76], high dietary fiber intake [77] and anti-inflammatory diets, like the MD, have positive effects on insulin secretion patterns [78]. Moreover, vegetarian diet also improves glycemic control in patients $[79,80]$. Hence, given the close relation between AD and T2DM, diet may also be an important link factor to modulate T2DM onset and AD risk.

\subsection{Gut Microbiota}

Gut microbiota encodes over three million genes producing thousands of metabolites with diverse roles, including extraction, synthesis, and absorption of many nutrients and metabolites [81]. Gut microbiota also shows an immune function against pathogenic bacteria colonization and promotes intestinal epithelium integrity [82-84]. It implies a wide range of microorganisms, being the dominant phyla Firmicutes and Bacteroidetes, which represents 90 percent of gut microbiota. Actinobacteria, Proteobacteria, Fusobacteria, and Verrucomicrobia, are also representative groups [85]. The human gut microbiota suffers taxonomic and functional modifications in each part of the gastro-intestinal tract. This leads 
to several variations in the same individual, due to age and environmental factors, although microbiota functions are preserved among individuals [86]. Additionally, modifications in the diversity or structure of gut microbiota known as dysbiosis, can affect metabolic activities, resulting in metabolic disorders, like obesity and diabetes. Consequently, dysbiosis may play a crucial role in the development of T2DM [32,87]. In this sense, it has been described that type 1 diabetes and T2DM patients show microbiota dysbiosis [88], which contributes to the onset and maintenance of insulin resistance [37]. Additionally, dietary habits can influence gut microbiota composition. In this sense, the Western diet (WD), a high-fat/high-sugar diet and low fiber intake, induces dysbiosis and it is associated with obesity and metabolic diseases [89]. On the other hand, studies using the MD have shown the benefits of modifying the intestinal microbiota in obese subjects for the prevention of the development of T2DM [89].

On the other hand, the brain-gut-microbiota axis also relates microbiota with brain pathologies like AD and Parkinson's disease [90,91]. Thus, AD patients present decreased microbial diversity, including reduced Firmicutes, and increased Bacteriodetes [92]. Furthermore, dementia patients with amyloidosis have increased pro-inflammatory cytokines levels in blood accompanied by increased pro-inflammatory intestinal bacteria [93]. It should be noted that several genera of gut microbiota can produce or metabolize neurotransmitters, such as $\gamma$-aminobutyric acid (GABA) [94], which play a relevant role in brain aging [95]. These findings position gut bacterial communities as a target for therapeutic intervention. Moreover, given the close relation between $\mathrm{AD}$ and metabolic alterations, gut microbiota could provide a relevant link between both pathologies. In this sense, undigested foods, microbes, endotoxins and immune response cause chronic inflammation that may ultimately contribute to alter the BBB integrity and trigger neuroinflammation [96]. Interestingly, a recent study shows that obesity, highly present in T2DM patients, impairs short-term and working memory through gut microbial metabolism of aromatic amino acids [3], offering a new venue that relates metabolic alterations and cognitive impairment.

\section{Diet, Inflammation and Gut Microbiota in AD Models}

Mouse models offer a good approximation to study human gut microbiota and their implications in diseases and inflammatory processes [97,98]. Despite appreciable differences between the intestinal tract of mice and humans [97], they share anatomical and physiological similarities [98]. Interestingly, whereas there are many variations at lower taxonomic level, gut microbiota composition shows similarities at a higher taxonomic level [99]. According to KEGG (Kyoto Encyclopedia of Genes and Genomes) database [100], when microbiome is analyzed dissimilarities are limited at functional level and mouse and human share $95.2 \%$ of the KEGG orthologous groups. Nevertheless, mice and humans only share $4.0 \%$ of the genes [99]. The mouse microbiome seems to have specifically enriched pathways involved in membrane transport, biodegradation and amino acids metabolism [99,101].

Diet and housing conditions may markedly influence the composition of the gut microbiome [84,99,102] together with the age [103], gender [104] and the genotype of the mice $[105,106]$. However, gut microbiome in mice is mainly composed by bacteria belonging to the phylum Bacteroidetes, followed by phyla Firmicutes, Deferribacteres $[99,101]$ and Proteobacteria [107], although the actual order depends on the studies [99].

As previously stated (Section 3.3. Gut microbiota), AD patients $[108,109]$ and AD preclinical models $[110,111]$ present significant dysbiosis and alterations in the composition of the microbiome. Concretely, APP/PS1 mice dysbiosis leads to alterations in metabolic and cellular pathways, including the phosphatidylinositol signaling system, limonene and pinene degradation, as well as butanoate/pyruvate metabolism [111]. Microbiome and their secretory products, such as lipopolysaccharide (LPS), are toxins that play a key role in the immune response [112,113] and are involved in microglial activation [114]. SCFAs (acetate, propionate and butyrate) are products of anaerobic bacteria fermentation of dietary fibers in the intestine. SCFAs are relevant gut-microbiota mediators of inflammation 
and immune response [115,116], they have a protective effect on epithelial cells [117] and decrease A $\beta$ fibrillation in vitro [118]. Propionate, a potent neurotoxic agent, is increased in 3xTg-AD mice by 6 months of age [119]. On the other hand, the concentration of SCFAs, including butyric and isobutyric acids, tend to be lower in both feces and brains from 3xTg-AD mice [111,119]. Likewise, gut microbiome can modulate the inflammatory response in both, the intestinal tract and the brain, through gut-brain axis $[115,120,121]$. Besides, gut microbiota is critical for microglia maturation [122,123] and activation in the CNS [122,124]. Activated microglia cells are significantly increased in the brains from 11-month 3xTg-AD mice [119] and, in germ-free APP/PS1 mice, a reduction of cortical microglia cells has been reported at 3.5 and 8 months of age [124]. Additionally, proinflammatory cytokines IL- 6 or IL- $1 \beta$, as well as lipocalin- 2 or TNF- $\alpha$ expression levels are increased in the colon of APP/PS1 mice by 3 and 6 months of age [125]. Similar results have been observed in SAMP8 mice, a spontaneous AD model, with colonic inflammation and high IL-1 $\beta$ levels [126]. Moreover, IL- $1 \beta$ was increased, while IFN- $\gamma$, IL-2 and IL-5 levels decreased in the brain from aged APP/PS1 mice [124]. In addition, a similar cytokines profile can be observed in plasma from 14-month 3xTg-AD mice, with higher levels of pro-inflammatory cytokines such as IL-12p40, whereas IL-1 $\alpha$, IL-1 $\beta$, IL-3, IL-5, IL-6, IL-12 p70, IL-17, TNF- $\alpha$, IFN- $\gamma$, CCL2, CCL3, CCL5, CCL11 and GM-CSF are decreased [127].

Gut-brain axis and gut microbiome seem to be fundamental for the load of $A \beta$ in the brain [124,128]. Previous studies have shown that germ-free APP/PS1 (amyloid precursor protein/presenilin 1) mice, have lower levels of $A \beta$, mainly $A \beta 42$, in brain and plasma, whereas colonization by microbiota from aged APP/PS1 mice results in increased levels of $A \beta$, supporting a close cross-talk between gut and brain in AD [124]. Moreover, APP/PS1 mice on long-term antibiotics treatment (gentamicin, vancomycin, metronidazole, neomycin, ampicillin, kanamycin, colistin and cefaperazone) show lower A $\beta$ plaque deposition and higher soluble $A \beta$ production, favoring $A \beta 42$ formation in the cortex and hippocampus [129]. In addition, wildtype fecal solution administered to APP/PS1 mice, previously treated with antibiotics, also results in lower $\mathrm{A} \beta$ deposition and better cognitive performance [130]. Similar outcomes have been described in ADLPAPT mice after transferring fecal microbiota from wildtype mice for 4 months. Treated ADLPAPT mice show lower SP burden and lower A $\beta$ levels [128].

Differences in gut microbiota are observed when wildtype and AD mice are compared (Table 1) $[107,111,131]$. Previous studies have reported lower bacterial diversity and more similar bacteria composition when young AD mice are compared with wildtype counterparts $[90,107,132]$, while further differences are shown as the age of the animals increase [90]. Following this idea, gut microbiota from young APP/PS1 mice [107] and 5xFAD mice $[131,133]$ are similar to that observed in wildtype animals. No significant differences in either $\alpha$ - or $\beta$-diversity have been observed in 5xFAD mice at 9-10 weeks old [133], although $\alpha$-diversity is lower in these mice by 6 and 12 months of age [134]. Nevertheless, $\alpha$-diversity, that conveys the diversity of species within a single sample, is significantly higher in wildtype mice compared to APP/PS1 mice by 9 months of age [135], although other studies have reported higher $\alpha$-diversity in the microbiota of APP/PS1 mice at the same age [90]. It also seems that $\alpha$-diversity is diminished with aging in APP/PS1 mice, as an indication of a worse health status of the host with aging [132]. On the other hand, $\beta$-diversity shows significant differences in the microbiome composition of APP/PS1 mice by 2, 6 [90] and 9 months of age [135] when compared with their wildtype counterparts. So, as disease progresses a marked temporal shift in the taxonomic distribution of principal phyla is detected, and the Firmicutes/Bacteroidetes ratio increases in APP/PS1 [107] and 5xFAD mice [131,134] in an age-dependent manner. An increase in Firmicutes/Bacteroidetes ratio is also observed when bacterial extracellular vesicles are analyzed in the serum of 8-month APP/PS1 mice [136]. Nevertheless, the ratio Firmicutes / Bacteroidetes is decreased in $\mathrm{APP}^{\mathrm{NL}-\mathrm{G}-\mathrm{F}}$ mice at this age [137], underlying the complexity of these studies. 
Table 1. Alterations of gut composition in AD preclinical models.

\begin{tabular}{|c|c|c|c|c|}
\hline Phylum & Class & Family & AD Mice & Ref. \\
\hline \multirow{2}{*}{ Actinobacteria } & \multirow{2}{*}{ Actinobacteria } & Turicibacteriaceae & $\begin{array}{l}=\text { in APP } / \text { PS1 mice } \\
\text { at } 6-24 \text { months of age }\end{array}$ & [107] \\
\hline & & Coriobacteriaceae & $\begin{array}{l}\uparrow \text { in APP /PS1 mice } \\
\text { at } 6-8 \text { months of age }\end{array}$ & [132] \\
\hline \multirow{4}{*}{ Bacteroidetes } & \multirow{4}{*}{ Bacteroidia } & Rikenellaceae & $\begin{array}{l}\downarrow \text { in APP/PS1 mice } \\
\text { at 6-24 months of age }\end{array}$ & {$[90,107]$} \\
\hline & & \multirow{3}{*}{$\begin{array}{l}\text { Bacteroidaceae (Genus } \\
\text { Prevotella) }\end{array}$} & $\begin{array}{l}\downarrow \text { in APP/PS1 mice } \\
\text { at } 3-6-8 \text { months of age }\end{array}$ & {$[90,132]$} \\
\hline & & & $\begin{array}{l}\downarrow \text { in } 5 x F A D \text { mice } \\
\text { at } 6-12 \text { months of age }\end{array}$ & [134] \\
\hline & & & $\uparrow$ in $3 x T g-A D$ at 11 months of age & [119] \\
\hline \multirow{12}{*}{ Firmicutes } & Erysipelotrichia & Erysipelotrichaceae & $\begin{array}{l}\uparrow \text { in APP /PS1 mice } \\
\text { at } 24 \text { months of age }\end{array}$ & {$[107,111]$} \\
\hline & \multirow{7}{*}{ Clostridia } & \multirow{3}{*}{ Ruminococcaceae } & $\begin{array}{l}\downarrow \text { Genus Ruminiclostridium in tg2576 mice } \\
\text { at } 6-15 \text { months of age }\end{array}$ & [138] \\
\hline & & & $\begin{array}{l}\downarrow \text { Genus Ruminococcus in APP/PS1 mice } \\
\text { at } 6-8 \text { months of age }\end{array}$ & {$[111,132]$} \\
\hline & & & $\begin{array}{c}\uparrow \text { Genus Ruminococcus in 5xFAD mice } \\
\text { at } 6-12 \text { months of age }\end{array}$ & [134] \\
\hline & & \multirow[b]{2}{*}{ Clostridiaceae } & $\begin{array}{c}\downarrow \text { Butyricicoccus pullicaecorum in APP/PS1 } \\
\text { mice at } 8-12 \text { months of age }\end{array}$ & [111] \\
\hline & & & $\begin{array}{c}\uparrow \text { transiently Clostridium leptum in } \\
5 x \text { FAD mice } \\
\text { at } 9 \text { weeks of age }\end{array}$ & [139] \\
\hline & & \multirow{2}{*}{ Lachnospiraceae } & $\begin{array}{l}\uparrow \text { in APP/PS1 mice } \\
\text { at } 3 \text { months of age }\end{array}$ & [90] \\
\hline & & & $\begin{array}{l}\uparrow \text { in } 5 x F A D \text { mice } \\
\text { at } 6 \text { months of age }\end{array}$ & [134] \\
\hline & \multirow{4}{*}{ Bacilli } & \multirow{4}{*}{$\begin{array}{l}\text { Lactobacillaceae (Genus } \\
\text { Lactobacillus) }\end{array}$} & $\begin{array}{c}\uparrow \text { in } \operatorname{Tg} 2576 \text { at } 6 \text { months of age } /=\text { at } \\
15 \text { months of age }\end{array}$ & [138] \\
\hline & & & $\begin{array}{l}\downarrow \text { in APP/PS1 mice } \\
\text { at } 8 \text { months of age }\end{array}$ & [140] \\
\hline & & & $\begin{array}{l}\uparrow \text { in } 3 \times T g-A D \text { mice } \\
\text { at } 11 \text { months of age }\end{array}$ & [119] \\
\hline & & & $\begin{array}{l}\downarrow \text { in } 5 x F A D \text { mice } \\
\text { at } 6 \text { months of age }\end{array}$ & [134] \\
\hline \multirow{6}{*}{ Proteobacteria } & \multirow[t]{2}{*}{$\beta$-proteobacteria } & \multirow{2}{*}{$\begin{array}{c}\text { Sutterellaceae } \\
\text { (Genus Sutterella) }\end{array}$} & $\begin{array}{l}\uparrow \text { in } \mathrm{APP} / \mathrm{PS} 1 \text { mice } \\
\text { at } 6 \text { months of age }\end{array}$ & [107] \\
\hline & & & $\uparrow$ in $5 x F A D$ mice at $6-12$ months of age & {$[134]$} \\
\hline & \multirow{2}{*}{$\delta$-proteobacteria } & \multirow{2}{*}{$\begin{array}{l}\text { Desulfovibrionaceae } \\
\text { (Genus Desulfovibrio) }\end{array}$} & $\begin{array}{l}\uparrow \text { in APP /PS1 mice } \\
\text { at } 5-9 \text { months of age }\end{array}$ & {$[111,130,132]$} \\
\hline & & & $\begin{array}{l}\uparrow \text { in } 5 x F A D \text { mice } \\
\text { at } 6-12 \text { months of age }\end{array}$ & [134] \\
\hline & \multirow{2}{*}{$\varepsilon$-proteobacteria } & \multirow{2}{*}{ Helicobacteraceae } & $\begin{array}{l}\uparrow \text { in APP/PS1 mice } \\
\text { at } 3-6-8 \text { months of age }\end{array}$ & {$[132]$} \\
\hline & & & $\begin{array}{l}\uparrow \text { in 5xFAD mice at } 6 \text { months of age } / \downarrow \text { at } \\
12 \text { months of age }\end{array}$ & [134] \\
\hline
\end{tabular}


Table 1. Cont.

\begin{tabular}{|c|c|c|c|c|}
\hline Phylum & Class & Family & AD Mice & Ref. \\
\hline & $\gamma$-proteobacteria & Enterobacteriaceae & $\begin{array}{l}\uparrow \text { in APP /PS1 mice } \\
\text { at } 6 \text { months of age }\end{array}$ & {$[90]$} \\
\hline \multirow{2}{*}{ Verrucomicrobia } & \multirow{2}{*}{ Verrucomicrobiae } & \multirow{2}{*}{$\begin{array}{l}\text { Verrucomicrobiaceae } \\
\text { (Akkermansia spp.) }\end{array}$} & $\begin{array}{l}\uparrow \uparrow \text { in APP/PS1 } \\
\text { at } 2-12 \text { months of age }\end{array}$ & {$[90,111,130]$} \\
\hline & & & $\begin{array}{c}\text { N.D. in 5xFAD mice at } 9 \text { weeks of age } / \uparrow \text { at } \\
12 \text { months of age }\end{array}$ & {$[134,139]$} \\
\hline
\end{tabular}

N.D.: not detected; =: no differences; $\downarrow$ : decrease; $\uparrow:$ increase; $\uparrow \uparrow:$ strong increase.

Gram-negative phylum Bacteroidetes, that are the main producers of acetate and propionate [141], seem to steadily increase with aging in both APP/PS1 and wildtype animals, but they are less abundant in APP/PS1 mice, being families Rikenellaceae [90,107] and Bacteroidaceae (genus Prevotella) [132] significantly lower in APP/PS1 mice [90]. A similar pattern is observed in 5xFAD mice at 6 and 12 months of age [134]. Oppositely, genus Prevotella seems to be increased in 3xTg-AD mice by 11 months of age [119].

On the other hand, gram-positive phylum Firmicutes, the main butyrate producingbacteria [141], increases with age and has higher presence in APP/PS1 animals than in wildtype mice by 24 months of age [107]. Similar outcomes have been reported in 5xFAD mice by 9 weeks of age [139] and in 15-month tg2576 mice [138]. This increase in Firmicutes, observed in AD models, is mainly due to members of the family Erysipelotrichaceae [107] and detected dysbiosis develops an immunogenic reaction [142] that is correlated with increased levels of proinflammatory cytokines, such as $\mathrm{TNF} \alpha$ [143]. By contrast, a decrease in the number of SCFAs and butyrate-producing bacteria is found in AD models. So, families Ruminococcaceae and Clostridiaceae (class Clostridia) are significantly decreased in 8-12-month APP/PS1 mice, accompanied by altered butanoate/pyruvate metabolism [111]. There is a positive correlation between the abundance in family Ruminococcaceae and the concentration of hypoxantine [144], an intermediate metabolite of purines which has a critical role in the maintenance of the intestinal barrier function [145] and it is altered in 6-month tg2576 mice [138]. Moreover, genus Ruminococcus (family Ruminococcaceae) is significantly lower in 8-months APP/PS1 mice, when spatial learning is aggravated in these mice [132]. Conversely, family Ruminococcaceae is increased in 5xFAD mice by 6 and 12 months of age [134] and it has been reported that Clostridium leptum is transiently increased in feces of 5xFAD mice at 9 weeks old, as a reflection of a compensatory mechanism in the early phases of AD [139].

In addition, 5xFAD mice have increased $\delta$-, $\gamma$ - and $\varepsilon$-Proteobacteria by 6 months of age, while at 12 months $\beta$ - and $\delta$-Proteobacteria are increased and $\varepsilon$-Proteobacteria is decreased when compared with wildtype counterparts [134]. In line with these observations, genus Desulfovibrio is reported to be highly increased in 5 to 9 month-old APP/PS1 mice microbiome $[90,111,130,132]$. As part of this phylum, the genus Sutterella (class $\beta$ Proteobacteria) is significantly increased in APP/PS1 mice in an age-dependent manner [107] and similar outcomes have been reported in 5xFAD mice at 12 months old [134]. Sutterella spp. specifically induces mild or negligible inflammatory responses and does not alter epithelial monolayer integrity [146], although they are increased in feces from patients with cognitive disorders [147]. Nevertheless, their immunomodulatory role is not fully understood [148]. Enterobacteriaceae is also increased in the microbiome of APP/PS1 mice by 6 months of age [90]. On the other hand, phylum Verrucomicrobia, and its only known genus, mucin-degrading bacteria Akkermansia, down-regulates the expression of the proinflammatory cytokines TNF- $\alpha$ and IFN- $\gamma$ in the colon [149]. Akkermansia is significantly increased in APP/PS1 mice along lifespan, starting at 2 months of age [90] up to 7 [130] and 12 months of age, when it is dramatically increased [111]. In 5xFAD mice, the presence of this phylum is limited in young mice, when compared to their wildtype counterparts [139], while it increases by 12 months of age [134]. 
The overall dysbiosis detected in AD mice (Table 1) leads to a proinflammatory microbiome that contributes to the inflammatory process [150]. As previously stated, dietary habits strongly influence the gut microbiota composition $[84,102]$. Therefore, new strategies try to favor a healthy microbiome through the administration of pre- and probiotics supplements as a possible treatment for AD [151]. In line with this, 3xTg-AD mice orally fed with probiotic SLAB51 (Streptococcus, Bifidobacteria, Lactobacilli) presented higher levels of Bifidobacterium spp. and reduced levels of Campylobacterales, along with an increase of anti-inflammatory SCFAs and cytokines that down-regulate inflammatory response. A reduction of amyloid load is also detected, accompanied by an improvement of cognitive alterations [152]. In other study, FRAMELIM ${ }^{\circledR}$ (Bifidobacterium, Lactobacillus, vitamins A, $\mathrm{D}$ and omega 3 fatty acid) administration to APP/PS1 mice successfully reduced brain $\mathrm{A} \beta$ burden, despite lowering the abundance of butyrate-producing bacteria [153]. Antioxidants, such as PW5 have also provoked a shift in gut microbiota composition from APP/PS1 mice, making them more similar to wildtype counterparts, while reducing SP in the hippocampus [154]. Although it has been described that pre- and probiotics have little effect on the microbiome of healthy population [155], the complexity of this research venue may require more in depth studies to fully elucidate their specific roles on microbiome and inflammation [156].

Caloric restriction diets have also been associated with an increase of dendritic spines in the dentate gyrus and cognitive protection in mice [157]. Intermittent fasting (IF) has also shown beneficial effects on neuropathological characteristics and cognitive deficits in AD [158-161]. IF leads to ketogenic metabolism, increasing $\beta$-hydroxybutyrate levels in serum and CSF [162]. Interestingly, $\beta$-hydroxybutyrate protects against A $\beta$ toxicity $[163,164]$ and protects hippocampal murine neurons $[165,166]$. Whereas previous studies have reported no significant effects of IF on neuroinflammation, synaptic plasticity or cognitive function in 6-month 5xFAD mice [167], it has also been shown that IF restores aquaporin-4 polarity, reduces SP deposition and ameliorates cognitive dysfunction in APP/PS1 mice [168]. Cognitive impairment is also improved in APPNL-G-F mice after IF for 9 months, whereas no significant effect is observed in amyloid load [169]. It has also been reported that IF for 3 months may increase brain-derived neurotrophic factor (BDNF) and neuronal differentiation in the dentate gyrus from 3xTg-AD mice [170]. In line with these observations, it has been shown that ketogenic diet reduces amyloid deposition and tau pathology, improving learning and memory tasks in a 3xTg-AD mouse model [171].

\section{Diet, Inflammation and Gut Microbiota in T2DM Models}

As previously stated, T2DM includes a heterogeneous group of metabolic disorders, characterized by hyperglycemia, and influenced by both genetic and environmental factors [172,173], in which lifestyle and dietary habits are strongly implicated [174]. The most commonly used T2DM mouse models are based on leptin signaling impairment [175], including $\mathrm{db} / \mathrm{db}$ and $\mathrm{ob} / \mathrm{ob}$ mice. Diet-induced models are also widely used, and different types of high-fat diet (HFD) are regularly administered to induce prediabetes, as well as to resemble the effects of WD [176-181]. HFD feeding increases body weight, leptin and insulin levels as well as insulin resistance in rodents [176,182,183]. Interestingly, the effects of HFD administration seems to be influenced by gut microbiota and the genetic background of the animals under study [184].

Inflammatory cells including neutrophils, abnormal lymphocytes and monocytes are increased in $\mathrm{db} / \mathrm{db}$ mice [185]. In line with these observations, CD68 mRNA, as a macrophage marker, is highly expressed in white adipose tissue in these mice [186]. In the CNS of $\mathrm{db} / \mathrm{db}$ mice, microglia cells are also increased [63] and exhibit greater reactivity to LPS stimulation [187]. In fact, LPS serum levels are markedly increased in $\mathrm{db} / \mathrm{db}$ mice [188]. Cytokines profile is also affected and $\mathrm{db} / \mathrm{db}$ mice and previous studies have shown an increase of pro-inflammatory cytokines, including IL-1 $\beta$ and TNF- $\alpha$ in serum [185], hippocampus [187] and liver [189]. CCL2, a chemokine that recruits monocytes and macrophages, is highly expressed in epididymal adipose tissue of $\mathrm{db} / \mathrm{db}$ mice [186], 
whereas the expression of nucleotide-binding-oligomerization domain type-1 (NOD1) is suppressed [186]. Inflammation also affects the vasculature and inflammatory markers such as monocyte chemotactic protein-1 (MCP-1), vascular cell adhesion molecule-1, (VCAM1), intercellular adhesion molecule-1 (ICAM1) or E-selectin are increased in aortic and carotid vessels from $\mathrm{db} / \mathrm{db}$ mice [190]. Likewise, oxidative stress markers, as like 3NT-positive protein, are increased in serum [191].

The ob/ob mouse also presents chronic inflammation of the adipose tissues which contributes to the metabolic pathogenesis of obesity and insulin resistance $[177,192,193]$. Cytokines and chemokines like TNF- $\alpha$, IL-1 $\beta$, IL-6, and CCL2 are overexpressed in visceral adipose tissue $[177,194]$. In line with these observations, elevated TNF- $\alpha$ levels lead to a decrease in Azgp1 mRNA and protein levels in adipose tissues of ob/ob mice $[177,192]$. Additionally, IL-6, TNF- $\alpha$ [195-197], IL-1 $\beta$, IL-10 [193] and plasminogen activator inhibitor1 (PAI-1) are increased in the adipose tissue and the spleen of ob/ob mice $[195,197]$. IFN- $\gamma$ expression decreases in ob/ob mice [193] and other studies have reported lower adiponectin values in the adipose tissue and in the spleen $[193,195]$. Moreover, LPS levels are higher in plasma from ob/ob mice [198] and in C57BL/6NTac mice on HFD [174]. Additionally, NF-kB levels are elevated in the brain of ob/ob mice [196]. Other markers, such as CD11 and CD86 are increased in the brain and visceral fat tissue, whereas the expression of CD206 decreases [196,197]. In line with these observations, oxidative stress is also severely affected in ob/ob animals and increased protein oxidation and lipoperoxidation are observed, accompanied by lower activity of antioxidant enzymes in kidney and heart [195].

As previously pointed out, diet is also an experimental approach to reproduce metabolic complications and mice fed a WD show infiltration of lymphocytes and neutrophils in the liver, indicating the presence of steatohepatitis, and increased TNF- $\alpha$-positive macrophages [199]. Animals on WD overexpress pro-inflammatory markers such as IL-1 $\beta$, IL-6, TNF- $\alpha$, FOXP3, SAA1, CCL17, CCL20 and ICAM-1 in the brain $[185,199]$ and CD68 expression is also increased in these mice [186]. The expression of NOD-1 is suppressed in mice fed with WD [186]. Following these observations, animals on HFD show an increase of crown-like structures and up-regulation of pro-inflammatory genes, indicating adipose tissue inflammation associated with diet [200]. Interestingly, whereas adipose tissue inflammation is observed after administration of HFD for 24 weeks, hepatic inflammation is not detected up to 40 weeks on HFD [200]. Moreover, adipose inflammation seems to contribute to insulin resistance more severely than hepatic inflammation [200]. In addition, He et al. found out that the phenotypic switch in adipose tissue from anti-inflammatory to pro-inflammatory macrophages is detected after 5 weeks on HFD, while metabolic inflammation is noted after 9 weeks [201]. An overall increase of pro-inflammatory cytokines such as TNF- $\alpha$, IL-6, leptin and TGF $\beta 1$ is detected in the liver of HFD-fed mice for 17 weeks [202] and up to 40 weeks [200]. Moreover, other markers, such as MCP-1, PAI-1 and CCL2 are increased in adipose tissue of mice on HFD for 9 weeks [176] or up to 17 weeks [202].

The gut microbiota in T2DM mice seems to be highly dependent on the genetic background and age of the animals under study [203-205] (Table 2). In ob/ob and $\mathrm{db} / \mathrm{db}$ mice Bacteroidetes and Firmicutes are the dominant phyla in the gut microbiota $[203,206]$, followed by Proteobacteria, Tenericutes, Actinobacteria and Cyanobacteria [203,207]. Other less abundant phyla found in these mice are Acidobacteria, Deferribacteres, Gemmatimonadetes, Lentishphaerae and Verrucomicrobia [205,208]. Additionally, the ratio Bacteroidetes/Firmicutes is higher in $\mathrm{db} / \mathrm{db}$ mice, than on C57Bl/6J mice [205]. On the other hand, family Muribaculaceae is reduced in $\mathrm{db} / \mathrm{db}$ mice by 8 months of age [209], while other studies have reported that genus Rikenella (family Rikenellaceae) is increased in $\mathrm{db} / \mathrm{db}$ mice by 6 months of age [210]. It also seems that genera Paraprevotella and Alloprevotella, (family Prevotellaceae) are increased in $\mathrm{db} / \mathrm{db}$ mice by 6 months of age, while the genus Alloprevotella decreases by 8 months of age [209,211]. Families Enterococcaceae and Planococcaceae (class Bacilli) [211], as well as genus Klebsiella (Enterobacteriaceae) are also increased in $\mathrm{db} / \mathrm{db}$ mice by 6 months of age [211]. 
Table 2. Alterations of gut composition in prediabetes and T2DM preclinical models.

\begin{tabular}{|c|c|c|c|c|}
\hline Phylum & Class & Family & Diabetes mice (db) & Reference \\
\hline \multirow{3}{*}{ Actinobacteria } & \multirow{3}{*}{ Actinobacteria } & Coriobacteriaceae & $\uparrow$ in $\mathrm{db} / \mathrm{db}$ mice at $8-12-18$ weeks of age & [205] \\
\hline & & $\begin{array}{l}\text { Dermabacteraceae } \\
\quad \text { (Genus } \\
\text { Brachybacterium) }\end{array}$ & $\uparrow$ in $\mathrm{db} / \mathrm{db}$ mice at $8-12-18$ weeks of age & [205] \\
\hline & & $\begin{array}{c}\text { Pseudonocardiaceae } \\
\text { (Genus Pseudonocardia) }\end{array}$ & $\uparrow$ in $\mathrm{db} / \mathrm{db}$ mice at 8-12-18 weeks of age & [205] \\
\hline \multirow{7}{*}{ Bacteroidetes } & \multirow{5}{*}{ Bacteroidia } & Muribaculaceae & $\downarrow$ in $\mathrm{db} / \mathrm{db}$ mice by 8 months of age & [209] \\
\hline & & \multirow[b]{2}{*}{ Rickenellaceae } & $\begin{array}{c}\uparrow \text { Genus Rikenella in HFD induced diabetic } \\
\text { mice by } 14 \text { weeks of age, after } 8 \text { weeks } \\
\text { of feeding }\end{array}$ & [206] \\
\hline & & & $\begin{array}{l}\uparrow \text { Genus Rikenella in } \mathrm{db} / \mathrm{db} \text { mice by } \\
\qquad 6 \text { months of age } \\
\downarrow \text { Genus Alistipes in } \mathrm{db} / \mathrm{db} \text { mice by } 20 \text { weeks } \\
-8 \text { months of age }\end{array}$ & [209-211] \\
\hline & & \multirow{2}{*}{$\begin{array}{c}\text { Bacteroidaceae } \\
\text { (Genus Bacteroides) }\end{array}$} & $\begin{array}{c}\downarrow \text { in } \mathrm{db} / \mathrm{db} \text { mice by } 20 \text { weeks of age } / \uparrow \text { by } \\
\text { 6-8 months of age }\end{array}$ & {$[204,209-211]$} \\
\hline & & & $\downarrow$ in ob/ob mice by 8 weeks of age & [211] \\
\hline & \multirow[t]{2}{*}{ Bacteroidetes } & Prevotellaceae & $\begin{array}{l}\uparrow \text { Genus Paraprevotella in } \mathrm{db} / \mathrm{db} \text { mice by } \\
6 \text { months of age } \\
\uparrow \text { Genus Alloprevotella in } \mathrm{db} / \mathrm{db} \text { mice by } \\
6 \text { months of age } / \downarrow \text { by } 8 \text { months of age }\end{array}$ & {$[209,211]$} \\
\hline & & Odoribacteraceae & $\begin{array}{l}\uparrow \text { in HFD induced diabetic mice by } 14 \\
\text { weeks of age, after } 8 \text { weeks of feeding }\end{array}$ & [206] \\
\hline \multirow{10}{*}{ Firmicutes } & \multirow{4}{*}{ Bacilli } & $\begin{array}{l}\text { Streptococcaceae } \\
\text { (Genus: Lactococcus) }\end{array}$ & $\begin{array}{l}\uparrow \text { in HFD induced diabetic mice by } 14 \\
\text { weeks of age, after } 8 \text { weeks of feeding }\end{array}$ & [206] \\
\hline & & $\begin{array}{c}\text { Enterococcaceae } \\
\text { (Genus Enterococcus) }\end{array}$ & $\uparrow$ in $\mathrm{db} / \mathrm{db}$ mice by 6 months of age & [211] \\
\hline & & $\begin{array}{l}\text { Planococcaceae } \\
\text { (Genus Kurthia) }\end{array}$ & $\uparrow$ in $\mathrm{db} / \mathrm{db}$ mice by 6 months of age & [211] \\
\hline & & $\begin{array}{c}\text { Lactobacillaceae } \\
\text { (Genus Lactobacillus) }\end{array}$ & $\uparrow$ in $\mathrm{db} / \mathrm{db}$ mice by 14 weeks of age & [206] \\
\hline & \multirow{6}{*}{ Clostridia } & \multirow[b]{2}{*}{ Ruminococcaceae } & $\uparrow$ in $\mathrm{db} / \mathrm{db}$ by 8 weeks & [205] \\
\hline & & & $\begin{array}{c}\uparrow \text { ob/ob mice by } 8 \text { weeks of age } \\
\uparrow \text { Genera Ruminococcus_1 and Oscillibacter in } \\
\text { ob/ob mice by 15-17 weeks of age }\end{array}$ & {$[203,206,211]$} \\
\hline & & \multirow{3}{*}{ Lachnospiraceae } & $\begin{array}{c}\uparrow \text { Genus Coprococcus in HFD induced } \\
\text { diabetic mice by } 14 \text { weeks of age, after } 8 \\
\text { weeks of feeding }\end{array}$ & [206] \\
\hline & & & $\begin{array}{c}\uparrow \text { Genera Lachnospiraceae_NK4A136 and } \\
\text { Agathobacter in ob/ob mice by } 15-17 \text { weeks } \\
\text { of age }\end{array}$ & {$[203,206]$} \\
\hline & & & $\downarrow$ in $\mathrm{db} / \mathrm{db}$ mice by 20 weeks of age & [204] \\
\hline & & $\begin{array}{c}\text { Clostridiaceae } \\
\text { (Genus Bacteroides) }\end{array}$ & $\uparrow$ in ob/ob mice by 8 weeks of age & [211] \\
\hline
\end{tabular}


Table 2. Cont

\begin{tabular}{|c|c|c|c|c|}
\hline Phylum & Class & Family & Diabetes mice (db) & Reference \\
\hline \multirow{7}{*}{ Proteobacteria } & $\alpha$-Proteobacteria & Bradyrhizobiaceae & $\uparrow$ in $\mathrm{db} / \mathrm{db}$ mice at $8-12-18$ weeks of age & {$[205]$} \\
\hline & \multirow{2}{*}{$\gamma$-Proteobacteria } & $\begin{array}{l}\text { Enterobacteriaceae } \\
\text { (Genus Klebsiella) }\end{array}$ & $\uparrow$ in $\mathrm{db} / \mathrm{db}$ mice by 6 months of age & {$[211]$} \\
\hline & & Moraxellaceae & $\uparrow$ in ob/ob mice at 8-12-18 weeks of age & {$[205]$} \\
\hline & \multirow{2}{*}{$\delta$-Proteobacteria } & \multirow{2}{*}{$\begin{array}{l}\text { Desulfovibrionaceae } \\
\text { (Genus Desulfovibrio) }\end{array}$} & $\uparrow$ in $\mathrm{db} / \mathrm{db}$ mice by 12 weeks & {$[205]$} \\
\hline & & & $\begin{array}{l}\uparrow \text { in HFD induced diabetic mice by } 14 \\
\text { weeks of age, after } 8 \text { weeks of feeding }\end{array}$ & {$[206]$} \\
\hline & \multirow{2}{*}{$\varepsilon$-Proteobacteria } & \multirow{2}{*}{ Helicobacteraceae } & $\begin{array}{l}\downarrow \text { Genus Helicobacter in STZ-induced } \\
\text { diabetic mice with cognitive disorder }\end{array}$ & {$[212]$} \\
\hline & & & $\begin{array}{l}\uparrow \text { in HFD induced diabetic mice by } 14 \\
\text { weeks of age, after } 8 \text { weeks of feeding }\end{array}$ & {$[206]$} \\
\hline Deferribacteres & Deferribacteres & Deferribacteraceae & $\begin{array}{c}\uparrow \text { Genera Deferribacter and Mucispirillum in } \\
\text { HFD induced diabetic mice by } 14 \text { weeks of } \\
\text { age, after } 8 \text { weeks of feeding }\end{array}$ & {$[206]$} \\
\hline
\end{tabular}

$\downarrow$ : decrease; $\uparrow:$ increase.

Interestingly, previous studies have suggested that T2DM pathology can be ameliorated by administering pre- and probiotics that may induce modifications in the microbiome [213-215]. Following this idea, treatment with Lactobacillus acidophilus reduces pro-inflammatory cytokines, including IL-8, TNF $\alpha$, and IL-1 $\beta$ in liver and colon of T2DM mice [87]. Prebiotic inulin modulates gut dysbiosis, increasing phylum Cyanobacteria and genus Bacteroides, that positively correlate with higher levels of IL-10 at early stages of T2DM, and negatively correlate with IL-6 and TNF- $\alpha$ in $\mathrm{db} / \mathrm{db}$ mice [216]. A reduction of Ruminiclostridium_6, Deferribacteres and Tenericutes is also detected in inulin-treated T2DM mice, that correlates with IL-6, TNF- $\alpha$ and IL-17A levels [216]. Additionally, diet supplements such as polysaccharides from mulberry fruit [217] and Alpinia oxyphyla Miq. extract [218], show beneficial effects at microbiome level in $\mathrm{db} / \mathrm{db}$ mice. Likewise, supplementation with Alpinia oxyphyla Miq. extract increases Akkermasia spp. while Helicobacter spp. is significantly reduced in $\mathrm{db} / \mathrm{db}$ mice [218]. Zhang et al., have reported that berberine and metformin treatment reduces LPS serum levels, relieve intestinal inflammation and repair intestinal barrier structures [188]. This treatment modifies gut microbiome in $\mathrm{db} / \mathrm{db}$ mice, increasing the number of SCFAs producing bacteria and Lactobacillus and Akkermansia, while decreasing opportunistic pathogens [188]. On the other hand, sodium-butyrate supplementation also ameliorates diabetic inflammation in $\mathrm{db} / \mathrm{db}$ mice, decreasing LPS and $\mathrm{HbA1c}$. It also decreases the ratio Firmicutes / Bacteroidetes [185]. In mice on HFD, 15 weeks treatment with baicalin, a flavonoid used in traditional Chinese medicine, rebalances the microbiota and SCFAs-producing agents specifically, to protect the intestinal system. Baicalin seems to regulate metabolic and immunological processes implicated in T2DM [219]. In line with these observations, another study, using the JinQi Jiangtang (Coptis chinensis, Astragalus membranaceus and Lonicera japonica), has reported reduced levels of TNF- $\alpha$ and IL-6, ameliorating the inflammatory response and regulating the intestinal microbiota [205]. Diabetic mice treated with $A$. membranaceus also show increased microbial diversity and enrichment of the bacterial Firmicutes spp., Acidobacteria and Gemmatimonodetes [212].

On the other hand, $\mathrm{db} / \mathrm{db}$ mice on IF show a reduction of $\mathrm{NF} \kappa \mathrm{B}$ activation and decreased LPS levels, associated with a significant improvement of cognitive function, limited neuroinflammatory response, restructured gut microbiota and metabolites [27,220] and reduced insulin resistance [207]. Other studies in $\mathrm{db} / \mathrm{db}$ mice on IF regimen for 28 days have reported a reduction of Enterococcus, Streptococcus, Enterococcaceae, Arthromitus, Rummeliibacillus that cause inflammation, while increasing Lactobacillus, accompanied by the attenuation of behavioral alterations [207]. 


\section{Microbiota, Inflammation and Diet in Preclinical Mixed Models in AD-T2DM}

The close relation between AD and T2DM has been largely documented [9,221-224]. While still limited, previous studies have reported the presence of AD-like pathological features related to alterations in the microbiota $[207,212,216,225,226]$ and the inflammatory response [227] in animal models that reproduce different metabolic alterations, suggesting that the gut-brain axis may explain the molecular similarities that link $\mathrm{AD}$ and T2DM $[228,229]$. Following this idea, it has been described that chronic bacterial infections are associated with amyloidosis, one of the pathological features shared by AD and T2DM [227].

Apolipoprotein E (APOE) 4 gene allele, the highest genetic risk factor for developing late-onset $\mathrm{AD}$, is associated with increased $\mathrm{A} \beta$ load, neuroinflammation and alterations in brain insulin signaling [230-233]. Studies on E4FAD mice, obtained for breeding 5xFAD mice with homozygous APOE4 mice, have shown that soluble $A \beta 42$ levels and total $A \beta$ levels are higher when compared to E2FAD and E3FAD mice. Moreover, SP deposition is higher and more compact in E4FAD mice, leading to neuroinflammation in the hippocampus [234]. ApoE $\mathrm{E}^{-/-}$mice on HFD have also shown higher APP expression [235] and increased $A \beta$ levels [236]. No significant differences have been observed in the expression of doublecortin or PSD95 in ApoE ${ }^{-/-}$and APOE4 mice on HFD, indicating that HFD does not affect neurogenesis and synaptic plasticity [237]. Some studies have shown that WD administration to adult APP/PS1 mice does not result in increased SP deposition or soluble A $\beta$ levels compared to animals on ND [238]. Nevertheless, the vast majority of available bibliography supports the deleterious effect of HDF administration. HFD increases hippocampal $\mathrm{A} \beta$ deposition in 5xFAD mice with no significant effect on memory [239]. APP/PS1 mice on HFD present a lower percentage of spines and deterioration of newborn neurons when compared with wildtype mice on normal diet (ND) [240]. Similarly, an exacerbation of synaptic loss has been detected in APP/PS1xdb/db mice [241]. Other studies have reported increased amyloid and tau pathologies, vascular damage and cognitive impairment in APP/PS1 mice on HFD [64]. Even short-term HFD [242] increases tau phosphorylation [236] and cognitive impairment is also increased 3xTg-AD on HFD [243]. Cognitive deficits might be due to loss of synaptic plasticity, since a reduction of matrix metalloproteinases $2 / 9$ activity accompanied by a decrease in the expression of the BDNF gene have been reported [238].

An overlap in the inflammatory mechanisms has also been described in AD and T2DM [244]. Previous findings confirmed that the microglial receptor for advanced glycation end products in T2DM may mediate microglial activation and neuroinflammation AD brains [244,245]. Increased neuroinflammation might not be exclusively related to HFD, since wildtype mice on HFD do not show a significant increase in the number of activated glial cells in the hippocampus, supporting a synergistic contribution when $\mathrm{AD}$ and metabolic disease are set together [240], as regularly observed in the clinic. MIP-1 $\alpha$, IL-1 $\beta$, and IL-17 are altered in the cortex from APP/PS1 mice on HFD that also show increased IL- $1 \beta$ and TNF- $\alpha$, accompanied by gliosis and disrupted neurogenesis in the hippocampus $[12,240]$. Higher levels of circulating blood monocytes, MCP-1, and ox-LDL are also observed in plasma from these mice, indicating severe systemic inflammation in these animals [238]. Interestingly, IL1- $\beta$, IL-12p70 and IL-13 correlate with insulin levels in APP/PS1xdb/db mice and IL-3, IL-17, IL-4, and KC (CXCL1) are also affected in these mice [12], suggesting that specific cytokine profiles are associated with $\mathrm{AD}$ and T2DM. In line with these observations, microglial activation is also increased 3xTg-AD on HFD [246].

An exacerbated production of pro-inflammatory cytokines, such as IL-1, IL-6 or TNF- $\alpha$ is observed in APOE4 mice [247]. Moreover, FAD mutations induce neuroinflammation in the hippocampus of APOE4 mice, by inducing the expression of genes for chemokine ligand 4, low-affinity Fc IgG receptor 4, chemokine 10 of the CXC motif, and $\alpha$-integrin increased [248]. On the other hand, $\mathrm{ApoE}^{-/-}$and APOE4 mice show significantly more inflammation in CA1 when fed with ND than wildtype mice, but these mice treated with 
HFD show decreased CD68 immunoreactivity in the hippocampus [237]. Furthermore, microbiome related inflammation may play a role at this level [249-251] since wildtype and $\mathrm{ApoE}^{-/-}$mice on HFD present higher LPS plasma levels and a higher expression of cytokines in the colon and hippocampus [235]. LPS induced endotoxemia in APOE4 mice results in an increase of plasma TNF $\alpha$ and G-CSF when compared with APOE3 mice. Besides, $\mathrm{CD} 8^{+} \mathrm{T}$ cell apoptosis is observed in APOE4 mice after LPS injection [249].

Diet-induced intestinal dysbiosis produces an imbalance in the microbiota that can have inflammatory consequences in the AD brain [106]. Interestingly, alteration of brain function and gut microbiota have been related to HFD administration during gestation [252]. Therefore, the disbalance in the composition of the gut microbiota could explain the altered eating behavior, memory impairment and abnormal exploratory performance of the offspring from mothers on HFD. Moreover, these studies may support the implications of early-life alterations in later development of neurodegenerative complications [253].

Specific assessment of 3xTg-AD mice on HFD showed a severe lack of the families Muribaculaceae, Peptococcaceae (genus rc4.4), Dehalobacteriaceae, accompanied by an excess of genus Clostridium (Table 3) [106]. This study confirms that HFD and genetic predisposition to neurodegenerative diseases share abnormalities in the microbiome and metabolome that are unfavorable for brain health. On the other hand, microbiota alterations associated with APOE have been found at 4 and 6-months of age, including changes in Prevotellaceae, Rikenellaceae, Gastranaerophilales, Lactobacillaceae, Peptococcaceae, Erysipelotrichaceae (genus Turicibacter), Desulfovibrionaceae and Mycoplasmataceae (genus Mollicutes) [250]. Moreover, E4FAD mice had a greater $\alpha$-diversity but reduced relative abundance of beneficial gut microbiota (Prevotella and Lactobacillus), accompanied by an increase of pro-inflammatory microbiota (Escherichia, Turicibacter and Akkermansia) (Table 3) [248]. However, Lactococcus, that has been implicated in a better performance in behavioral tests, is not present in $\mathrm{ApoE}^{-/-}$animals [235].

Table 3. Alterations of gut composition in $\mathrm{AD}$ and metabolic disease animal models.

\begin{tabular}{|c|c|c|c|c|}
\hline Phylum & Class & Family & Mixed-Model (AD-Metabolic Disease) & Ref. \\
\hline \multirow{2}{*}{ Bacteroidetes } & Bacteroidia & Muribaculaceae & $\downarrow$ in $3 x T g-A D-H F D$ mice & [106] \\
\hline & Bacteroidetes & Prevotellaceae & $\downarrow$ Genus Prevotella in E4FAD mice & [248] \\
\hline \multirow{6}{*}{ Firmicutes } & Erysipelotrichia & Erysipelotrichaceae & $\uparrow$ Genus Turicibacter in E4FAD mice & [248] \\
\hline & \multirow{3}{*}{ Clostridia } & Clostridiaceae & $\begin{array}{l}\uparrow \uparrow \text { Genus Clostridium in 3xTg-AD-HFD } \\
\text { mice }\end{array}$ & [106] \\
\hline & & Dehalobacteriaceae & $\downarrow$ in $3 x T g-A D-H F D$ mice & [106] \\
\hline & & Peptococcaceae & $\downarrow$ in $3 x T g-A D-H F D$ mice & [106] \\
\hline & \multirow[b]{2}{*}{ Bacilli } & Lactobacillaceae & $\downarrow$ Genus Lactobacillus in E4FAD mice & [248] \\
\hline & & Streptococcaceae & $\begin{array}{l}\text { Genus Lactococcus not present in } \\
\text { APOE-/- mice }\end{array}$ & [235] \\
\hline Proteobacteria & $\gamma$-proteobacteria & Enterobacteriaceae & $\uparrow$ Genus Escherichia in E4FAD mice & [248] \\
\hline Verrucomicrobia & Verrucomicrobiae & $\begin{array}{l}\text { Verrucomicrobiaceae } \\
\text { (Akkermansia spp.) }\end{array}$ & $\uparrow$ in E4FAD mice & [248] \\
\hline
\end{tabular}

$\downarrow$ : decrease; $\uparrow:$ increase; $\uparrow \uparrow:$ strong increase.

Caloric restriction has been considered an experimental diet that can lengthen the lifespan in various animal models [254-256] and may help to establish a balanced architecture of the intestinal microbiota with beneficial effects on the health of the host by reducing the intestinal antigen load [256]. Other diet strategies to ameliorate AD symptoms are based in prebiotics such as inulin that stimulates the growth and activity of SCFAs-producing bacteria. Inulin administration also reduces proinflammatory gene expression in the hippocampus and $A \beta$ deposits in E4FAD mice [248]. It also contributed to a larger size of the caecum, improving the microbial content, even before the development of the $A \beta$ 
pathology in E4FAD mice. An improvement in systemic metabolism associated to the modulation of the intestinal microbiome has also observed in this model [248]. Although further studies would be necessary to understand the functional and morphological characteristics mediated by inflammation, microbiota, and diet in mixed preclinical models of AD-T2DM, observations based on experimental animal models may contribute to the development of optimal techniques and therapies to reverse the complications associated with AD and metabolic alterations.

\section{Common Microbiota Alterations in AD, T2DM and Mixed Preclinical Models}

$\mathrm{AD}$ and T2DM share common pathological features that include impairment in insulin signaling, alteration of amyloid and tau pathologies or vascular damage that have been largely revised before (Mejido, Penny et al., 2020; Goncalves et al., 2019; Ferreira et al., 2019; Vieira et al., 2018). At inflammatory level, as stated in this review and in previous studies, proinflammatory cytokines are favored in AD, T2DM and mixed preclinical models. Among others, it has been shown that IL- $1 \beta$ is increased in the brain from aged APP/PS1 [124] as well as in APP/PS1xdb/db mice [12]. IL-1 $\beta$ and TNF- $\alpha$ are also increased in the brain from $\mathrm{db} / \mathrm{db}$ mice [187] as well as in APP/PS1 mice on HFD [12,240].

Whereas the role of the gut microbiota as a feasible connection between both diseases remain largely unexplored, some common links have been reported (Graphic Abstract). Bacteroidetes and Firmicutes are the dominant phyla in AD, T2DM and mixed models $[85,203,206]$. Bacteroidetes (family Muribaculaceae) is reduced in $\mathrm{db} / \mathrm{db}$ mice at 8 months of age [209] and 3xTg-AD mice on HFD also show a severe lack of Bacteroidetes [106]. This phylum (family Prevotellaceae) is also decreased in E4FAD and db/db mice at 8 months of age $[209,211,248]$. Actinobacteria (family Coriobacteriaceae) has been reported to be increased both in APP/PS1 [132] and in $\mathrm{db} / \mathrm{db}$ mice [205], while the Bacteroidaceae family seems to be less abundant in different AD and T2DM preclinical models [90,132,134,204,209-211,257]. Nevertheless, other studies have reported increases in the Bacteroidaceae family, both in AD [119] and T2DM animals [204,209-211]. Phylum Firmicutes (family Ruminococcaceae, genus Ruminococcus) has been reported to be increased in AD [134] as well as in different T2DM preclinical models $[203,205,206]$. The Clostridiaceae family is transiently increased in the feces of 5xFAD mice at 9 weeks [139]. Similarly, it is increased in ob/ob mice at 8 weeks of age [257] and an excess of the genus Clostridium is observed in 3xTg-AD mice on HFD [106]. Other studies have reported that the Lachnospiraceae family is more abundant in AD preclinical models (3 month-old APP / PS1 mice and 5xFAD mice at 6 months of age) $[90,134]$ as well as in metabolic disease preclinical models (both after HFD administration and in 15-17 week old ob/ob mice) $[203,206]$. Likewise, the family Lactobacillaceae has been shown to be increased in AD mice (6 month-old Tg2576 and 11 month-old 3xTg-AD mice) $[119,138]$ and similar outcomes have been reported in $\mathrm{db} / \mathrm{db}$ mice at 14 weeks of age [206]. Other alterations include increases of the Enterobacteriaceae family in $\mathrm{db} / \mathrm{db}$ and AD mice, including 6 month-old APP/PS1 [90] and E4FAD mice [248]. The Desulfovibrionaceae family (Genus Desulfovibrio) is also increased in 5-9 month-old APP/PS1 [111,130,132] and 6-12 month-old 5xFAD mice [134]. Similar outcomes have been reported in 12-week-old db/db mice [205] and after HFD administration [206]. It has also been shown that family Helicobacteraceae is increased in 3-8 month-old APP/PS1 mice, 6 month-old 5xFAD mice and after HFD administration $[132,134,206]$, supporting similar changes in AD and metabolic disease models. Interestingly, previous studies suggest that AD and T2DM pathologies can improve through the treatment of pre-and probiotics [87,151-153,248,258], caloric restriction diets $[27,157,207,220]$ or antioxidants [154], helping to regulate intestinal dysbiosis and reduce the inflammation.

\section{Conclusions}

The extensive review of available bibliography shows that gut microbiota composition, and the brain-gut axis are affected in AD, T2DM and mixed models of AD and metabolic disorders, affecting inflammation through products of bacterial metabolism, like SCAFs. 
Proinflammatory cytokines are widely altered in mouse models of both diseases. Microbiota is highly affected as diseases progress, and alterations in Actinobacteria, Bacteroidetes or Firmicutes phyla, among others, are commonly observed in animal models harboring $\mathrm{AD}, \mathrm{T} 2 \mathrm{DM}$ or $\mathrm{AD}$ and metabolic disease. All these observations based on preclinical models have contributed to further understand the key role of the gut-brain axis in both pathologies. Nevertheless, conflicting results have also been reported and therefore further studies would be necessary to fully understand the relation between diet, microbiota and inflammation in $\mathrm{AD}$ and T2DM.

Author Contributions: M.J.C.-N., M.V.-S. manuscript drafting and revision, C.H.-B., G.B.-N. and M.G.A. writing and revision for critical content, C.I.-G. and A.d.M. study concept, design, manuscript drafting and revision. All authors have read and agreed to the published version of the manuscript.

Funding: M.G.-A.: Programa Estatal de I+D+I orientada a los Retos de la Sociedad (BFU 2016-75038$\mathrm{R})$, financed by the Agencia Estatal de Investigación (AEI) and the Fondo Europeo de Desarrollo Regional (FEDER). Subvencion para la Financiacion de la Investigación y la Innovación Biomedica y en Ciencias de la Salud en el Marco de la Iniciativa Territorial Integrada 2014-2020 para la provincia de Cadiz. Consejeria de Salud y Familias. Junta de Andalucia and financed by the Fondo de Desarrollo Regional (FEDER) (PI-0008-2017). Union Europea.

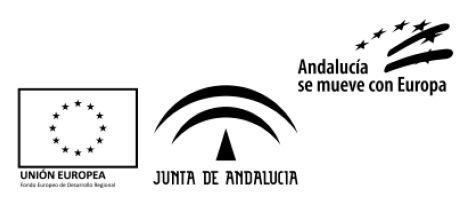

Conflicts of Interest: The authors declare no conflict of interest.

\section{References}

1. Arvanitakis, Z.; Shah, R.C.; Bennett, D.A. Diagnosis and Management of Dementia: Review. JAMA 2019, 322, 1589-1599. [CrossRef] [PubMed]

2. Alzheimer's_Association. 2017 Alzheimer's disease facts and figures. Alzheimer's Dement. 2017, 13, 325-373. [CrossRef]

3. Arnoriaga-Rodríguez, M.; Mayneris-Perxachs, J.; Burokas, A.; Contreras-Rodríguez, O.; Blasco, G.; Coll, C.; Biarnés, C.; Miranda-Olivos, R.; Latorre, J.; Moreno-Navarrete, J.M.; et al. Obesity Impairs Short-Term and Working Memory through Gut Microbial Metabolism of Aromatic Amino Acids. Cell Metab. 2020, 32, 548-560.e547. [CrossRef]

4. Bloom, G.S. Amyloid-beta and tau: The trigger and bullet in Alzheimer disease pathogenesis. JAMA Neurol. 2014, 71, 505-508. [CrossRef] [PubMed]

5. Spires-Jones, T.L.; Hyman, B.T. The intersection of amyloid beta and tau at synapses in Alzheimer's disease. Neuron 2014, 82, 756-771. [CrossRef] [PubMed]

6. Calvo-Rodriguez, M.; de la Fuente, C.; Garcia-Durillo, M.; Garcia-Rodriguez, C.; Villalobos, C.; Nunez, L. Aging and amyloid beta oligomers enhance TLR4 expression, LPS-induced $\mathrm{Ca}(2+)$ responses, and neuron cell death in cultured rat hippocampal neurons. J. Neuroinflamm. 2017, 14, 24. [CrossRef] [PubMed]

7. Serrano-Pozo, A.; Frosch, M.P.; Masliah, E.; Hyman, B.T. Neuropathological alterations in Alzheimer disease. Cold Spring Harb. Perspect. Med. 2011, 1, a006189. [CrossRef] [PubMed]

8. Esquerda-Canals, G.; Montoliu-Gaya, L.; Guell-Bosch, J.; Villegas, S. Mouse Models of Alzheimer's Disease. J. Alzheimer's Dis. 2017, 57, 1171-1183. [CrossRef] [PubMed]

9. Heneka, M.T.; Carson, M.J.; El Khoury, J.; Landreth, G.E.; Brosseron, F.; Feinstein, D.L.; Jacobs, A.H.; Wyss-Coray, T.; Vitorica, J.; Ransohoff, R.M.; et al. Neuroinflammation in Alzheimer's disease. Lancet Neurol. 2015, 14, 388-405. [CrossRef]

10. Calsolaro, V.; Edison, P. Neuroinflammation in Alzheimer's disease: Current evidence and future directions. Alzheimer's Dement. 2016, 12, 719-732. [CrossRef] [PubMed]

11. Habib, N.; McCabe, C.; Medina, S.; Varshavsky, M.; Kitsberg, D.; Dvir-Szternfeld, R.; Green, G.; Dionne, D.; Nguyen, L.; Marshall, J.L.; et al. Disease-associated astrocytes in Alzheimer's disease and aging. Nat. Neurosci. 2020, 23, 701-706. [CrossRef]

12. Sankar, S.B.; Infante-Garcia, C.; Weinstock, L.D.; Ramos-Rodriguez, J.J.; Hierro-Bujalance, C.; Fernandez-Ponce, C.; Wood, L.B.; Garcia-Alloza, M. Amyloid beta and diabetic pathology cooperatively stimulate cytokine expression in an Alzheimer's mouse model. J. Neuroinflamm. 2020, 17, 38. [CrossRef] [PubMed]

13. Wes, P.D.; Sayed, F.A.; Bard, F.; Gan, L. Targeting microglia for the treatment of Alzheimer's Disease. Glia 2016, 64, 1710-1732. [CrossRef] [PubMed]

14. Zhao, R.; Hu, W.; Tsai, J.; Li, W.; Gan, W.B. Microglia limit the expansion of beta-amyloid plaques in a mouse model of Alzheimer's disease. Mol. Neurodegener. 2017, 12, 47. [CrossRef] 
15. Hickman, S.E.; Allison, E.K.; El Khoury, J. Microglial dysfunction and defective beta-amyloid clearance pathways in aging Alzheimer's disease mice. J. Neurosci. 2008, 28, 8354-8360. [CrossRef]

16. Lucin, K.M.; Wyss-Coray, T. Immune activation in brain aging and neurodegeneration: Too much or too little? Neuron 2009, 64, 110-122. [CrossRef]

17. Zhuang, Z.; Yang, R.; Wang, W.; Qi, L.; Huang, T. Associations between gut microbiota and Alzheimer's disease, major depressive disorder, and schizophrenia. J. Neuroinflamm. 2020, 17, 288. [CrossRef] [PubMed]

18. Goyal, D.; Ali, S.A.; Singh, R.K. Emerging role of gut microbiota in modulation of neuroinflammation and neurodegeneration with emphasis on Alzheimer's disease. Prog. Neuropsychopharmacol. Biol. Psychiatry 2020, 110112. [CrossRef]

19. Zhuang, Z.Q.; Shen, L.L.; Li, W.W.; Fu, X.; Zeng, F.; Gui, L.; Lu, Y.; Cai, M.; Zhu, C.; Tan, Y.L.; et al. Gut Microbiota is Altered in Patients with Alzheimer's Disease. J. Alzheimer's Dis. 2018, 63, 1337-1346. [CrossRef]

20. Laiteerapong, N.; Ham, S.A.; Gao, Y.; Moffet, H.H.; Liu, J.Y.; Huang, E.S.; Karter, A.J. The Legacy Effect in Type 2 Diabetes: Impact of Early Glycemic Control on Future Complications (The Diabetes \& Aging Study). Diabetes Care 2019, 42, 416-426. [CrossRef]

21. Pratley, R.E. Type 2 diabetes is one of the leading causes of premature morbidity and mortality. Introduction. Am. J. Med. 2013, 126, S1. [CrossRef] [PubMed]

22. Saeedi, P.; Petersohn, I.; Salpea, P.; Malanda, B.; Karuranga, S.; Unwin, N.; Colagiuri, S.; Guariguata, L.; Motala, A.A.; Ogurtsova, K.; et al. Global and regional diabetes prevalence estimates for 2019 and projections for 2030 and 2045 : Results from the International Diabetes Federation Diabetes Atlas, 9(th) edition. Diabetes Res. Clin. Pract. 2019, 157, 107843. [CrossRef] [PubMed]

23. Tabak, A.G.; Herder, C.; Rathmann, W.; Brunner, E.J.; Kivimaki, M. Prediabetes: A high-risk state for diabetes development. Lancet 2012, 379, 2279-2290. [CrossRef]

24. Esser, N.; Utzschneider, K.M.; Kahn, S.E. Early beta cell dysfunction vs insulin hypersecretion as the primary event in the pathogenesis of dysglycaemia. Diabetologia 2020, 63, 2007-2021. [CrossRef] [PubMed]

25. Zheng, Y.; Ley, S.H.; Hu, F.B. Global aetiology and epidemiology of type 2 diabetes mellitus and its complications. Nat. Rev. Endocrinol. 2018, 14, 88-98. [CrossRef]

26. Fazeli Farsani, S.; van der Aa, M.P.; van der Vorst, M.M.; Knibbe, C.A.; de Boer, A. Global trends in the incidence and prevalence of type 2 diabetes in children and adolescents: A systematic review and evaluation of methodological approaches. Diabetologia 2013, 56, 1471-1488. [CrossRef]

27. Liu, J.; Ren, Z.H.; Qiang, H.; Wu, J.; Shen, M.; Zhang, L.; Lyu, J. Trends in the incidence of diabetes mellitus: Results from the Global Burden of Disease Study 2017 and implications for diabetes mellitus prevention. BMC Public Health 2020, $20,1415$. [CrossRef]

28. Liu, C.; Feng, X.; Li, Q.; Wang, Y.; Li, Q.; Hua, M. Adiponectin, TNF-alpha and inflammatory cytokines and risk of type 2 diabetes: A systematic review and meta-analysis. Cytokine 2016, 86, 100-109. [CrossRef] [PubMed]

29. Chen, P.C.; Chien, Y.W.; Yang, S.C. The alteration of gut microbiota in newly diagnosed type 2 diabetic patients. Nutrition 2019, 63-64, 51-56. [CrossRef]

30. Hur, K.Y.; Lee, M.S. Gut Microbiota and Metabolic Disorders. Diabetes Metab. J. 2015, 39, 198-203. [CrossRef]

31. Palacios, T.; Vitetta, L.; Coulson, S.; Madigan, C.D.; Denyer, G.S.; Caterson, I.D. The effect of a novel probiotic on metabolic biomarkers in adults with prediabetes and recently diagnosed type 2 diabetes mellitus: Study protocol for a randomized controlled trial. Trials 2017, 18, 7. [CrossRef]

32. Vallianou, N.G.; Stratigou, T.; Tsagarakis, S. Microbiome and diabetes: Where are we now? Diabetes Res. Clin. Pract. 2018, 146, 111-118. [CrossRef]

33. Grasset, E.; Burcelin, R. The gut microbiota to the brain axis in the metabolic control. Rev. Endocr. Metab. Disord. 2019, 20, 427-438. [CrossRef]

34. Farre, R.; Fiorani, M.; Abdu Rahiman, S.; Matteoli, G. Intestinal Permeability, Inflammation and the Role of Nutrients. Nutrients 2020, 12, 1185. [CrossRef]

35. Sharma, S.; Tripathi, P. Gut microbiome and type 2 diabetes: Where we are and where to go? J. Nutr. Biochem. 2019, 63, 101-108. [CrossRef] [PubMed]

36. Qin, J.; Li, Y.; Cai, Z.; Li, S.; Zhu, J.; Zhang, F.; Liang, S.; Zhang, W.; Guan, Y.; Shen, D.; et al. A metagenome-wide association study of gut microbiota in type 2 diabetes. Nature 2012, 490, 55-60. [CrossRef]

37. Sircana, A.; Framarin, L.; Leone, N.; Berrutti, M.; Castellino, F.; Parente, R.; De Michieli, F.; Paschetta, E.; Musso, G. Altered Gut Microbiota in Type 2 Diabetes: Just a Coincidence? Curr. Diabetes Rep. 2018, 18, 98. [CrossRef]

38. Lin, H.V.; Frassetto, A.; Kowalik, E.J., Jr.; Nawrocki, A.R.; Lu, M.M.; Kosinski, J.R.; Hubert, J.A.; Szeto, D.; Yao, X.; Forrest, G.; et al. Butyrate and propionate protect against diet-induced obesity and regulate gut hormones via free fatty acid receptor 3-independent mechanisms. PLoS ONE 2012, 7, e35240. [CrossRef] [PubMed]

39. Kellow, N.J.; Coughlan, M.T.; Savige, G.S.; Reid, C.M. Effect of dietary prebiotic supplementation on advanced glycation, insulin resistance and inflammatory biomarkers in adults with pre-diabetes: A study protocol for a double-blind placebo-controlled randomised crossover clinical trial. BMC Endocr. Disord. 2014, 14, 55. [CrossRef]

40. Kandimalla, R.; Thirumala, V.; Reddy, P.H. Is Alzheimer's disease a Type 3 Diabetes? A critical appraisal. Biochim. Biophys. Acta Mol. Basis Dis. 2017, 1863, 1078-1089. [CrossRef] 
41. Andreu-Reinon, M.E.; Huerta, J.M.; Gavrila, D.; Amiano, P.; Mar, J.; Tainta, M.; Ardanaz, E.; Larumbe, R.; Navarro, C.; Colorado-Yohar, S.M.; et al. Incidence of Dementia and Associated Factors in the EPIC-Spain Dementia Cohort. J. Alzheimer's Dis. 2020. [CrossRef] [PubMed]

42. de Bruijn, R.F.; Bos, M.J.; Portegies, M.L.; Hofman, A.; Franco, O.H.; Koudstaal, P.J.; Ikram, M.A. The potential for prevention of dementia across two decades: The prospective, population-based Rotterdam Study. BMC Med. 2015, 13, 132. [CrossRef] [PubMed]

43. Frison, E.; Dufouil, C.; Helmer, C.; Berr, C.; Auriacombe, S.; Chene, G. Diabetes-Associated Dementia Risk and Competing Risk of Death in the Three-City Study. J. Alzheimer's Dis. 2019, 71, 1339-1350. [CrossRef]

44. Luchsinger, J.A.; Palta, P.; Rippon, B.; Sherwood, G.; Soto, L.; Ceballos, F.; Laing, K.; Igwe, K.; He, H.; Razlighi, Q.; et al. Pre-Diabetes, but not Type 2 Diabetes, Is Related to Brain Amyloid in Late Middle-Age. J. Alzheimer's Dis. 2020, 75, 1241-1252. [CrossRef] [PubMed]

45. Chatterjee, S.; Mudher, A. Alzheimer's Disease and Type 2 Diabetes: A Critical Assessment of the Shared Pathological Traits. Front. Neurosci. 2018, 12, 383. [CrossRef]

46. Mittal, K.; Katare, D.P. Shared links between type 2 diabetes mellitus and Alzheimer's disease: A review. Diabetes Metab. Syndr. 2016, 10, S144-S149. [CrossRef] [PubMed]

47. Nam, G.E.; Park, Y.G.; Han, K.; Kim, M.K.; Koh, E.S.; Kim, E.S.; Lee, M.K.; Kim, B.; Hong, O.K.; Kwon, H.S. BMI, Weight Change, and Dementia Risk in Patients with New-Onset Type 2 Diabetes: A Nationwide Cohort Study. Diabetes Care 2019, 42, 1217-1224. [CrossRef] [PubMed]

48. Wium-Andersen, I.K.; Osler, M.; Jorgensen, M.B.; Rungby, J.; Wium-Andersen, M.K. Antidiabetic medication and risk of dementia in patients with type 2 diabetes: A nested case-control study. Eur. J. Endocrinol. 2019, 181, 499-507. [CrossRef]

49. Guilliams, M.; Mildner, A.; Yona, S. Developmental and Functional Heterogeneity of Monocytes. Immunity 2018, 49, 595-613. [CrossRef]

50. Chaney, A.; Williams, S.R.; Boutin, H. In vivo molecular imaging of neuroinflammation in Alzheimer's disease. J. Neurochem. 2019, 149, 438-451. [CrossRef]

51. Ozben, T.; Ozben, S. Neuro-inflammation and anti-inflammatory treatment options for Alzheimer's disease. Clin. Biochem. 2019, 72, 87-89. [CrossRef]

52. Di Filippo, M.; Chiasserini, D.; Gardoni, F.; Viviani, B.; Tozzi, A.; Giampa, C.; Costa, C.; Tantucci, M.; Zianni, E.; Boraso, M.; et al. Effects of central and peripheral inflammation on hippocampal synaptic plasticity. Neurobiol. Dis. 2013, 52, 229-236. [CrossRef]

53. Condello, C.; Yuan, P.; Grutzendler, J. Microglia-Mediated Neuroprotection, TREM2, and Alzheimer's Disease: Evidence from Optical Imaging. Biol. Psychiatry 2018, 83, 377-387. [CrossRef]

54. Tejera, D.; Heneka, M.T. Microglia in Alzheimer's disease: The good, the bad and the ugly. Curr. Alzheimer Res. 2016, 13, 370-380. [CrossRef]

55. Barroeta-Espar, I.; Weinstock, L.D.; Perez-Nievas, B.G.; Meltzer, A.C.; Siao Tick Chong, M.; Amaral, A.C.; Murray, M.E.; Moulder, K.L.; Morris, J.C.; Cairns, N.J.; et al. Distinct cytokine profiles in human brains resilient to Alzheimer's pathology. Neurobiol. Dis. 2019, 121, 327-337. [CrossRef]

56. Park, K.W.; Baik, H.H.; Jin, B.K. IL-13-induced oxidative stress via microglial NADPH oxidase contributes to death of hippocampal neurons in vivo. J. Immunol 2009, 183, 4666-4674. [CrossRef]

57. Zhou, J.; Yu, W.; Zhang, M.; Tian, X.; Li, Y.; Lu, Y. Imbalance of Microglial TLR4/TREM2 in LPS-Treated APP/PS1 Transgenic Mice: A Potential Link Between Alzheimer's Disease and Systemic Inflammation. Neurochem. Res. 2019, 44, 1138-1151. [CrossRef]

58. Swardfager, W.; Lanctot, K.; Rothenburg, L.; Wong, A.; Cappell, J.; Herrmann, N. A meta-analysis of cytokines in Alzheimer's disease. Biol. Psychiatry 2010, 68, 930-941. [CrossRef] [PubMed]

59. Newcombe, E.A.; Camats-Perna, J.; Silva, M.L.; Valmas, N.; Huat, T.J.; Medeiros, R. Inflammation: The link between comorbidities, genetics, and Alzheimer's disease. J. Neuroinflamm. 2018, 15, 276. [CrossRef] [PubMed]

60. Haghani, K.; Pashaei, S.; Vakili, S.; Taheripak, G.; Bakhtiyari, S. TNF-alpha knockdown alleviates palmitate-induced insulin resistance in C2C12 skeletal muscle cells. Biochem. Biophys. Res. Commun. 2015, 460, 977-982. [CrossRef] [PubMed]

61. Copps, K.D.; White, M.F. Regulation of insulin sensitivity by serine/threonine phosphorylation of insulin receptor substrate proteins IRS1 and IRS2. Diabetologia 2012, 55, 2565-2582. [CrossRef]

62. Infante-Garcia, C.; Ramos-Rodriguez, J.J.; Galindo-Gonzalez, L.; Garcia-Alloza, M. Long-term central pathology and cognitive impairment are exacerbated in a mixed model of Alzheimer's disease and type 2 diabetes. Psychoneuroendocrinology 2016, 65, 15-25. [CrossRef] [PubMed]

63. Ramos-Rodriguez, J.J.; Jimenez-Palomares, M.; Murillo-Carretero, M.I.; Infante-Garcia, C.; Berrocoso, E.; Hernandez-Pacho, F.; Lechuga-Sancho, A.M.; Cozar-Castellano, I.; Garcia-Alloza, M. Central vascular disease and exacerbated pathology in a mixed model of type 2 diabetes and Alzheimer's disease. Psychoneuroendocrinology 2015, 62, 69-79. [CrossRef] [PubMed]

64. Ramos-Rodriguez, J.J.; Ortiz-Barajas, O.; Gamero-Carrasco, C.; de la Rosa, P.R.; Infante-Garcia, C.; Zopeque-Garcia, N.; Lechuga-Sancho, A.M.; Garcia-Alloza, M. Prediabetes-induced vascular alterations exacerbate central pathology in APPswe/PS1dE9 mice. Psychoneuroendocrinology 2014, 48, 123-135. [CrossRef]

65. Scarmeas, N.; Anastasiou, C.A.; Yannakoulia, M. Nutrition and prevention of cognitive impairment. Lancet Neurol. 2018, 17, 1006-1015. [CrossRef]

66. Spector, R. Nutrient transport systems in brain: 40 years of progress. J. Neurochem. 2009, 111, 315-320. [CrossRef] 
67. Hooshmand, B.; Mangialasche, F.; Kalpouzos, G.; Solomon, A.; Kareholt, I.; Smith, A.D.; Refsum, H.; Wang, R.; Muhlmann, M.; Ertl-Wagner, B.; et al. Association of Vitamin B12, Folate, and Sulfur Amino Acids with Brain Magnetic Resonance Imaging Measures in Older Adults: A Longitudinal Population-Based Study. JAMA Psychiatry 2016, 73, 606-613. [CrossRef]

68. Van der Zwaluw, N.L.; Brouwer-Brolsma, E.M.; van de Rest, O.; van Wijngaarden, J.P.; In't Veld, P.H.; Kourie, D.I.; Swart, K.M.; Enneman, A.W.; van Dijk, S.C.; van der Velde, N.; et al. Folate and Vitamin B12-Related Biomarkers in Relation to Brain Volumes. Nutrients 2016, 9, 8. [CrossRef]

69. Szczechowiak, K.; Diniz, B.S.; Leszek, J. Diet and Alzheimer's dementia-Nutritional approach to modulate inflammation. Pharm. Biochem. Behav. 2019, 184, 172743. [CrossRef]

70. Valls-Pedret, C.; Sala-Vila, A.; Serra-Mir, M.; Corella, D.; de la Torre, R.; Martinez-Gonzalez, M.A.; Martinez-Lapiscina, E.H.; Fito, M.; Perez-Heras, A.; Salas-Salvado, J.; et al. Mediterranean Diet and Age-Related Cognitive Decline: A Randomized Clinical Trial. JAMA Intern Med. 2015, 175, 1094-1103. [CrossRef]

71. Rusek, M.; Pluta, R.; Ulamek-Koziol, M.; Czuczwar, S.J. Ketogenic Diet in Alzheimer's Disease. Int. J. Mol. Sci. 2019, 20, 3892. [CrossRef]

72. Morrill, S.J.; Gibas, K.J. Ketogenic diet rescues cognition in ApoE4+ patient with mild Alzheimer's disease: A case study. Diabetes Metab. Syndr. 2019, 13, 1187-1191. [CrossRef]

73. Ota, M.; Matsuo, J.; Ishida, I.; Takano, H.; Yokoi, Y.; Hori, H.; Yoshida, S.; Ashida, K.; Nakamura, K.; Takahashi, T.; et al. Effects of a medium-chain triglyceride-based ketogenic formula on cognitive function in patients with mild-to-moderate Alzheimer's disease. Neurosci. Lett. 2019, 690, 232-236. [CrossRef] [PubMed]

74. Witte, A.V.; Fobker, M.; Gellner, R.; Knecht, S.; Floel, A. Caloric restriction improves memory in elderly humans. Proc. Natl. Acad. Sci. USA 2009, 106, 1255-1260. [CrossRef] [PubMed]

75. Garcia-Molina, L.; Lewis-Mikhael, A.M.; Riquelme-Gallego, B.; Cano-Ibanez, N.; Oliveras-Lopez, M.J.; Bueno-Cavanillas, A. Improving type 2 diabetes mellitus glycaemic control through lifestyle modification implementing diet intervention: A systematic review and meta-analysis. Eur. J. Nutr. 2020, 59, 1313-1328. [CrossRef]

76. Al-Rashed, F.; Alghaith, A.; Azim, R.; AlMekhled, D.; Thomas, R.; Sindhu, S.; Ahmad, R. Increasing the Duration of Light Physical Activity Ameliorates Insulin Resistance Syndrome in Metabolically Healthy Obese Adults. Cells 2020, 9, 1189. [CrossRef]

77. Tucker, L.A. Fiber Intake and Insulin Resistance in 6374 Adults: The Role of Abdominal Obesity. Nutrients 2018, 10, 237. [CrossRef]

78. Greco, M.; Chiefari, E.; Montalcini, T.; Accattato, F.; Costanzo, F.S.; Pujia, A.; Foti, D.; Brunetti, A.; Gulletta, E. Early effects of a hypocaloric, Mediterranean diet on laboratory parameters in obese individuals. Mediat. Inflamm. 2014, 2014, 750860. [CrossRef] [PubMed]

79. Barnard, N.D.; Cohen, J.; Jenkins, D.J.; Turner-McGrievy, G.; Gloede, L.; Jaster, B.; Seidl, K.; Green, A.A.; Talpers, S. A low-fat vegan diet improves glycemic control and cardiovascular risk factors in a randomized clinical trial in individuals with type 2 diabetes. Diabetes Care 2006, 29, 1777-1783. [CrossRef]

80. Lee, Y.; Park, K. Adherence to a Vegetarian Diet and Diabetes Risk: A Systematic Review and Meta-Analysis of Observational Studies. Nutrients 2017, 9, 603. [CrossRef]

81. Valdes, A.M.; Walter, J.; Segal, E.; Spector, T.D. Role of the gut microbiota in nutrition and health. BMJ 2018, 361, k2179. [CrossRef]

82. Khosravi, A.; Mazmanian, S.K. Disruption of the gut microbiome as a risk factor for microbial infections. Curr. Opin. Microbiol. 2013, 16, 221-227. [CrossRef]

83. Voth, E.; Khanna, S. Fecal microbiota transplantation for treatment of patients with recurrent Clostridioides difficile infection. Expert Rev. Anti Infect. Ther. 2020, 1-8. [CrossRef]

84. Rinninella, E.; Cintoni, M.; Raoul, P.; Lopetuso, L.R.; Scaldaferri, F.; Pulcini, G.; Miggiano, G.A.D.; Gasbarrini, A.; Mele, M.C. Food Components and Dietary Habits: Keys for a Healthy Gut Microbiota Composition. Nutrients 2019, 11, 2393. [CrossRef] [PubMed]

85. Arumugam, M.; Raes, J.; Pelletier, E.; Le Paslier, D.; Yamada, T.; Mende, D.R.; Fernandes, G.R.; Tap, J.; Bruls, T.; Batto, J.M.; et al. Enterotypes of the human gut microbiome. Nature 2011, 473, 174-180. [CrossRef]

86. Rinninella, E.; Raoul, P.; Cintoni, M.; Franceschi, F.; Miggiano, G.A.D.; Gasbarrini, A.; Mele, M.C. What is the Healthy Gut Microbiota Composition? A Changing Ecosystem across Age, Environment, Diet, and Diseases. Microorganisms 2019, 7, 14. [CrossRef] [PubMed]

87. Yan, F.; Li, N.; Shi, J.; Li, H.; Yue, Y.; Jiao, W.; Wang, N.; Song, Y.; Huo, G.; Li, B. Lactobacillus acidophilus alleviates type 2 diabetes by regulating hepatic glucose, lipid metabolism and gut microbiota in mice. Food Funct. 2019, 10, 5804-5815. [CrossRef] [PubMed]

88. Ejtahed, H.S.; Hoseini-Tavassol, Z.; Khatami, S.; Zangeneh, M.; Behrouzi, A.; Ahmadi Badi, S.; Moshiri, A.; Hasani-Ranjbar, S.; Soroush, A.R.; Vaziri, F.; et al. Main gut bacterial composition differs between patients with type 1 and type 2 diabetes and non-diabetic adults. J. Diabetes Metab. Disord. 2020, 19, 265-271. [CrossRef]

89. Zinöcker, M.K.; Lindseth, I.A. The Western Diet-Microbiome-Host Interaction and Its Role in Metabolic Disease. Nutrients 2018, 10, 365. [CrossRef]

90. Chen, Y.; Fang, L.; Chen, S.; Zhou, H.; Fan, Y.; Lin, L.; Li, J.; Xu, J.; Chen, Y.; Ma, Y.; et al. Gut Microbiome Alterations Precede Cerebral Amyloidosis and Microglial Pathology in a Mouse Model of Alzheimer's Disease. Biomed. Res. Int. 2020, $2020,8456596$. [CrossRef]

91. Minato, T.; Maeda, T.; Fujisawa, Y.; Tsuji, H.; Nomoto, K.; Ohno, K.; Hirayama, M. Progression of Parkinson's disease is associated with gut dysbiosis: Two-year follow-up study. PLoS ONE 2017, 12, e0187307. [CrossRef] 
92. Vogt, N.M.; Kerby, R.L.; Dill-McFarland, K.A.; Harding, S.J.; Merluzzi, A.P.; Johnson, S.C.; Carlsson, C.M.; Asthana, S.; Zetterberg, H.; Blennow, K.; et al. Gut microbiome alterations in Alzheimer's disease. Sci. Rep. 2017, 7, 13537. [CrossRef]

93. Cattaneo, A.; Cattane, N.; Galluzzi, S.; Provasi, S.; Lopizzo, N.; Festari, C.; Ferrari, C.; Guerra, U.P.; Paghera, B.; Muscio, C.; et al. Association of brain amyloidosis with pro-inflammatory gut bacterial taxa and peripheral inflammation markers in cognitively impaired elderly. Neurobiol. Aging 2017, 49, 60-68. [CrossRef]

94. Strandwitz, P.; Kim, K.H.; Terekhova, D.; Liu, J.K.; Sharma, A.; Levering, J.; McDonald, D.; Dietrich, D.; Ramadhar, T.R.; Lekbua, A.; et al. GABA-modulating bacteria of the human gut microbiota. Nat. Microbiol. 2019, 4, 396-403. [CrossRef]

95. Huang, D.; Liu, D.; Yin, J.; Qian, T.; Shrestha, S.; Ni, H. Glutamate-glutamine and GABA in brain of normal aged and patients with cognitive impairment. Eur. Radiol. 2017, 27, 2698-2705. [CrossRef] [PubMed]

96. Riccio, P.; Rossano, R. Undigested Food and Gut Microbiota May Cooperate in the Pathogenesis of Neuroinflammatory Diseases: A Matter of Barriers and a Proposal on the Origin of Organ Specificity. Nutrients 2019, 11, 2714. [CrossRef]

97. Hugenholtz, F.; de Vos, W.M. Mouse models for human intestinal microbiota research: A critical evaluation. Cell Mol. Life Sci. 2018, 75, 149-160. [CrossRef] [PubMed]

98. Nguyen, T.L.; Vieira-Silva, S.; Liston, A.; Raes, J. How informative is the mouse for human gut microbiota research? Dis. Model Mech. 2015, 8, 1-16. [CrossRef]

99. Xiao, L.; Feng, Q.; Liang, S.; Sonne, S.B.; Xia, Z.; Qiu, X.; Li, X.; Long, H.; Zhang, J.; Zhang, D.; et al. A catalog of the mouse gut metagenome. Nat. Biotechnol. 2015, 33, 1103-1108. [CrossRef] [PubMed]

100. Ogata, H.; Goto, S.; Sato, K.; Fujibuchi, W.; Bono, H.; Kanehisa, M. KEGG: Kyoto Encyclopedia of Genes and Genomes. Nucleic Acids Res. 1999, 27, 29-34. [CrossRef]

101. Chung, Y.W.; Gwak, H.J.; Moon, S.; Rho, M.; Ryu, J.H. Functional dynamics of bacterial species in the mouse gut microbiome revealed by metagenomic and metatranscriptomic analyses. PLoS ONE 2020, 15, e0227886. [CrossRef] [PubMed]

102. Senghor, B.; Sokhna, C.; Ruimy, R.; Lagier, J.-C. Gut microbiota diversity according to dietary habits and geographical provenance. Hum. Microbiome J. 2018, 7-8, 1-9. [CrossRef]

103. Fransen, F.; van Beek, A.A.; Borghuis, T.; Aidy, S.E.; Hugenholtz, F.; van der Gaast-de Jongh, C.; Savelkoul, H.F.J.; De Jonge, M.I.; Boekschoten, M.V.; Smidt, H.; et al. Aged Gut Microbiota Contributes to Systemical Inflammaging after Transfer to Germ-Free Mice. Front. Immunol. 2017, 8, 1385. [CrossRef]

104. Elderman, M.; Hugenholtz, F.; Belzer, C.; Boekschoten, M.; van Beek, A.; de Haan, B.; Savelkoul, H.; de Vos, P.; Faas, M. Sex and strain dependent differences in mucosal immunology and microbiota composition in mice. Biol. Sex Differ. 2018, 9, 26. [CrossRef] [PubMed]

105. Maldonado Weng, J.; Parikh, I.; Naqib, A.; York, J.; Green, S.J.; Estus, S.; LaDu, M.J. Synergistic effects of APOE and sex on the gut microbiome of young EFAD transgenic mice. Mol. Neurodegener. 2019, 14, 47. [CrossRef]

106. Sanguinetti, E.; Collado, M.C.; Marrachelli, V.G.; Monleon, D.; Selma-Royo, M.; Pardo-Tendero, M.M.; Burchielli, S.; Iozzo, P. Microbiome-metabolome signatures in mice genetically prone to develop dementia, fed a normal or fatty diet. Sci. Rep. 2018, 8, 4907. [CrossRef]

107. Bauerl, C.; Collado, M.C.; Diaz Cuevas, A.; Vina, J.; Perez Martinez, G. Shifts in gut microbiota composition in an APP/PSS1 transgenic mouse model of Alzheimer's disease during lifespan. Lett. Appl. Microbiol. 2018, 66, 464-471. [CrossRef] [PubMed]

108. Liu, P.; Wu, L.; Peng, G.; Han, Y.; Tang, R.; Ge, J.; Zhang, L.; Jia, L.; Yue, S.; Zhou, K.; et al. Altered microbiomes distinguish Alzheimer's disease from amnestic mild cognitive impairment and health in a Chinese cohort. Brain Behav. Immun. 2019, 80, 633-643. [CrossRef]

109. Stadlbauer, V.; Engertsberger, L.; Komarova, I.; Feldbacher, N.; Leber, B.; Pichler, G.; Fink, N.; Scarpatetti, M.; Schippinger, W.; Schmidt, R.; et al. Dysbiosis, gut barrier dysfunction and inflammation in dementia: A pilot study. BMC Geriatr. 2020, 20, 248. [CrossRef]

110. Peng, W.; Yi, P.; Yang, J.; Xu, P.; Wang, Y.; Zhang, Z.; Huang, S.; Wang, Z.; Zhang, C. Association of gut microbiota composition and function with a senescence-accelerated mouse model of Alzheimer's Disease using 16S rRNA gene and metagenomic sequencing analysis. Aging 2018, 10, 4054-4065. [CrossRef] [PubMed]

111. Zhang, L.; Wang, Y.; Xiayu, X.; Shi, C.; Chen, W.; Song, N.; Fu, X.; Zhou, R.; Xu, Y.F.; Huang, L.; et al. Altered Gut Microbiota in a Mouse Model of Alzheimer's Disease. J. Alzheimer's Dis. 2017, 60, 1241-1257. [CrossRef]

112. Lukiw, W.J. Gastrointestinal (GI) Tract Microbiome-Derived Neurotoxins-Potent Neuro-Inflammatory Signals From the GI Tract via the Systemic Circulation into the Brain. Front. Cell. Infect. Microbiol. 2020, 10, 22. [CrossRef]

113. Zhao, Y.; Jaber, V.; Lukiw, W.J. Secretory Products of the Human GI Tract Microbiome and Their Potential Impact on Alzheimer's Disease (AD): Detection of Lipopolysaccharide (LPS) in AD Hippocampus. Front. Cell. Infect. Microbiol. 2017, 7, 318. [CrossRef] [PubMed]

114. Hoogland, I.C.M.; Westhoff, D.; Engelen-Lee, J.Y.; Melief, J.; Valls Seron, M.; Houben-Weerts, J.; Huitinga, I.; van Westerloo, D.J.; van der Poll, T.; van Gool, W.A.; et al. Microglial Activation after Systemic Stimulation with Lipopolysaccharide and Escherichia coli. Front. Cell. Neurosci. 2018, 12, 110. [CrossRef]

115. Luu, M.; Weigand, K.; Wedi, F.; Breidenbend, C.; Leister, H.; Pautz, S.; Adhikary, T.; Visekruna, A. Regulation of the effector function of CD8(+) T cells by gut microbiota-derived metabolite butyrate. Sci. Rep. 2018, 8, 14430. [CrossRef] [PubMed]

116. Silva, Y.P.; Bernardi, A.; Frozza, R.L. The Role of Short-Chain Fatty Acids from Gut Microbiota in Gut-Brain Communication. Front. Endocrinol. 2020, 11, 25. [CrossRef] [PubMed] 
117. Li, M.; van Esch, B.; Wagenaar, G.T.M.; Garssen, J.; Folkerts, G.; Henricks, P.A.J. Pro- and anti-inflammatory effects of short chain fatty acids on immune and endothelial cells. Eur. J. Pharm. 2018, 831, 52-59. [CrossRef]

118. Ho, L.; Ono, K.; Tsuji, M.; Mazzola, P.; Singh, R.; Pasinetti, G.M. Protective roles of intestinal microbiota derived short chain fatty acids in Alzheimer's disease-type beta-amyloid neuropathological mechanisms. Expert Rev. Neurother. 2018, 18, 83-90. [CrossRef]

119. Syeda, T.; Sanchez-Tapia, M.; Pinedo-Vargas, L.; Granados, O.; Cuervo-Zanatta, D.; Rojas-Santiago, E.; Diaz-Cintra, S.A.; Torres, N.; Perez-Cruz, C. Bioactive Food Abates Metabolic and Synaptic Alterations by Modulation of Gut Microbiota in a Mouse Model of Alzheimer's Disease. J. Alzheimer's Dis. 2018, 66, 1657-1682. [CrossRef]

120. Burokas, A.; Arboleya, S.; Moloney, R.D.; Peterson, V.L.; Murphy, K.; Clarke, G.; Stanton, C.; Dinan, T.G.; Cryan, J.F. Targeting the Microbiota-Gut-Brain Axis: Prebiotics Have Anxiolytic and Antidepressant-like Effects and Reverse the Impact of Chronic Stress in Mice. Biol. Psychiatry 2017, 82, 472-487. [CrossRef] [PubMed]

121. Lundberg, R.; Toft, M.F.; Metzdorff, S.B.; Hansen, C.H.F.; Licht, T.R.; Bahl, M.I.; Hansen, A.K. Human microbiota-transplanted C57BL/ 6 mice and offspring display reduced establishment of key bacteria and reduced immune stimulation compared to mouse microbiota-transplantation. Sci. Rep. 2020, 10, 7805. [CrossRef]

122. Erny, D.; Hrabe de Angelis, A.L.; Jaitin, D.; Wieghofer, P.; Staszewski, O.; David, E.; Keren-Shaul, H.; Mahlakoiv, T.; Jakobshagen, K.; Buch, T.; et al. Host microbiota constantly control maturation and function of microglia in the CNS. Nat. Neurosci. 2015, 18, 965-977. [CrossRef]

123. Matcovitch-Natan, O.; Winter, D.R.; Giladi, A.; Vargas Aguilar, S.; Spinrad, A.; Sarrazin, S.; Ben-Yehuda, H.; David, E.; Zelada Gonzalez, F.; Perrin, P.; et al. Microglia development follows a stepwise program to regulate brain homeostasis. Science 2016, 353, aad8670. [CrossRef] [PubMed]

124. Harach, T.; Marungruang, N.; Duthilleul, N.; Cheatham, V.; Mc Coy, K.D.; Frisoni, G.; Neher, J.J.; Fak, F.; Jucker, M.; Lasser, T.; et al. Reduction of Abeta amyloid pathology in APPPS1 transgenic mice in the absence of gut microbiota. Sci. Rep. 2017, 7, 41802. [CrossRef] [PubMed]

125. Manocha, G.D.; Floden, A.M.; Miller, N.M.; Smith, A.J.; Nagamoto-Combs, K.; Saito, T.; Saido, T.C.; Combs, C.K. Temporal progression of Alzheimer's disease in brains and intestines of transgenic mice. Neurobiol. Aging 2019, 81, 166-176. [CrossRef]

126. Pellegrini, C.; Daniele, S.; Antonioli, L.; Benvenuti, L.; D'Antongiovanni, V.; Piccarducci, R.; Pietrobono, D.; Citi, V.; Piragine, E.; Flori, L.; et al. Prodromal Intestinal Events in Alzheimer's Disease (AD): Colonic Dysmotility and Inflammation Are Associated with Enteric AD-Related Protein Deposition. Int. J. Mol. Sci. 2020, 21, 3523. [CrossRef] [PubMed]

127. Yang, S.H.; Kim, J.; Lee, M.J.; Kim, Y. Abnormalities of plasma cytokines and spleen in senile APP/PS1/Tau transgenic mouse model. Sci. Rep. 2015, 5, 15703. [CrossRef]

128. Kim, M.S.; Kim, Y.; Choi, H.; Kim, W.; Park, S.; Lee, D.; Kim, D.K.; Kim, H.J.; Choi, H.; Hyun, D.W.; et al. Transfer of a healthy microbiota reduces amyloid and tau pathology in an Alzheimer's disease animal model. Gut 2020, 69, 283-294. [CrossRef]

129. Minter, M.R.; Zhang, C.; Leone, V.; Ringus, D.L.; Zhang, X.; Oyler-Castrillo, P.; Musch, M.W.; Liao, F.; Ward, J.F.; Holtzman, D.M.; et al. Antibiotic-induced perturbations in gut microbial diversity influences neuro-inflammation and amyloidosis in a murine model of Alzheimer's disease. Sci. Rep. 2016, 6, 30028. [CrossRef]

130. Sun, J.; Xu, J.; Ling, Y.; Wang, F.; Gong, T.; Yang, C.; Ye, S.; Ye, K.; Wei, D.; Song, Z.; et al. Fecal microbiota transplantation alleviated Alzheimer's disease-like pathogenesis in APP/PS1 transgenic mice. Transl. Psychiatry 2019, 9, 189. [CrossRef]

131. Chen, C.; Ahn, E.H.; Kang, S.S.; Liu, X.; Alam, A.; Ye, K. Gut dysbiosis contributes to amyloid pathology, associated with C/EBPbeta/AEP signaling activation in Alzheimer's disease mouse model. Sci. Adv. 2020, 6, eaba0466. [CrossRef]

132. Shen, L.; Liu, L.; Ji, H.F. Alzheimer's Disease Histological and Behavioral Manifestations in Transgenic Mice Correlate with Specific Gut Microbiome State. J. Alzheimer's Dis. 2017, 56, 385-390. [CrossRef] [PubMed]

133. Dos Santos Guilherme, M.; Todorov, H.; Osterhof, C.; Mollerke, A.; Cub, K.; Hankeln, T.; Gerber, S.; Endres, K. Impact of Acute and Chronic Amyloid-beta Peptide Exposure on Gut Microbial Commensals in the Mouse. Front. Microbiol. 2020, $11,1008$. [CrossRef]

134. Lee, H.J.; Lee, K.E.; Kim, J.K.; Kim, D.H. Suppression of gut dysbiosis by Bifidobacterium longum alleviates cognitive decline in 5XFAD transgenic and aged mice. Sci. Rep. 2019, 9, 11814. [CrossRef] [PubMed]

135. Wang, S.; Jiang, W.; Ouyang, T.; Shen, X.Y.; Wang, F.; Qu, Y.H.; Zhang, M.; Luo, T.; Wang, H.Q. Jatrorrhizine Balances the Gut Microbiota and Reverses Learning and Memory Deficits in APP/PS1 transgenic mice. Sci. Rep. 2019, 9, 19575. [CrossRef] [PubMed]

136. Park, J.Y.; Choi, J.; Lee, Y.; Lee, J.E.; Lee, E.H.; Kwon, H.J.; Yang, J.; Jeong, B.R.; Kim, Y.K.; Han, P.L. Metagenome Analysis of Bodily Microbiota in a Mouse Model of Alzheimer Disease Using Bacteria-derived Membrane Vesicles in Blood. Exp. Neurobiol. 2017, 26, 369-379. [CrossRef]

137. Kaur, H.; Nagamoto-Combs, K.; Golovko, S.; Golovko, M.Y.; Klug, M.G.; Combs, C.K. Probiotics ameliorate intestinal pathophysiology in a mouse model of Alzheimer's disease. Neurobiol. Aging 2020, 92, 114-134. [CrossRef]

138. Honarpisheh, P.; Reynolds, C.R.; Blasco Conesa, M.P.; Moruno Manchon, J.F.; Putluri, N.; Bhattacharjee, M.B.; Urayama, A.; McCullough, L.D.; Ganesh, B.P. Dysregulated Gut Homeostasis Observed Prior to the Accumulation of the Brain Amyloid-beta in Tg2576 Mice. Int. J. Mol. Sci. 2020, 21, 1711. [CrossRef]

139. Brandscheid, C.; Schuck, F.; Reinhardt, S.; Schafer, K.H.; Pietrzik, C.U.; Grimm, M.; Hartmann, T.; Schwiertz, A.; Endres, K. Altered Gut Microbiome Composition and Tryptic Activity of the 5xFAD Alzheimer's Mouse Model. J. Alzheimer's Dis. 2017, 56, 775-788. [CrossRef] 
140. Sun, J.; Liu, S.; Ling, Z.; Wang, F.; Ling, Y.; Gong, T.; Fang, N.; Ye, S.; Si, J.; Liu, J. Fructooligosaccharides Ameliorating Cognitive Deficits and Neurodegeneration in APP/PS1 Transgenic Mice through Modulating Gut Microbiota. J. Agric. Food Chem. 2019, 67, 3006-3017. [CrossRef]

141. Parada Venegas, D.; De la Fuente, M.K.; Landskron, G.; Gonzalez, M.J.; Quera, R.; Dijkstra, G.; Harmsen, H.J.M.; Faber, K.N.; Hermoso, M.A. Short Chain Fatty Acids (SCFAs)-Mediated Gut Epithelial and Immune Regulation and Its Relevance for Inflammatory Bowel Diseases. Front. Immunol. 2019, 10, 277. [CrossRef]

142. Palm, N.W.; de Zoete, M.R.; Cullen, T.W.; Barry, N.A.; Stefanowski, J.; Hao, L.; Degnan, P.H.; Hu, J.; Peter, I.; Zhang, W.; et al. Immunoglobulin A coating identifies colitogenic bacteria in inflammatory bowel disease. Cell 2014, 158, 1000-1010. [CrossRef]

143. Dinh, D.M.; Volpe, G.E.; Duffalo, C.; Bhalchandra, S.; Tai, A.K.; Kane, A.V.; Wanke, C.A.; Ward, H.D. Intestinal microbiota, microbial translocation, and systemic inflammation in chronic HIV infection. J. Infect. Dis. 2015, 211, 19-27. [CrossRef] [PubMed]

144. Wakita, Y.; Shimomura, Y.; Kitada, Y.; Yamamoto, H.; Ohashi, Y.; Matsumoto, M. Taxonomic classification for microbiome analysis, which correlates well with the metabolite milieu of the gut. BMC Microbiol. 2018, 18, 188. [CrossRef] [PubMed]

145. Lee, J.S.; Wang, R.X.; Alexeev, E.E.; Lanis, J.M.; Battista, K.D.; Glover, L.E.; Colgan, S.P. Hypoxanthine is a checkpoint stress metabolite in colonic epithelial energy modulation and barrier function. J. Biol. Chem. 2018, 293, 6039-6051. [CrossRef]

146. Kaakoush, N.O. Sutterella Species, IgA-degrading Bacteria in Ulcerative Colitis. Trends Microbiol. 2020, 28, 519-522. [CrossRef]

147. Wang, L.; Christophersen, C.T.; Sorich, M.J.; Gerber, J.P.; Angley, M.T.; Conlon, M.A. Increased abundance of Sutterella spp. and Ruminococcus torques in feces of children with autism spectrum disorder. Mol. Autism 2013, 4, 42. [CrossRef]

148. Hiippala, K.; Kainulainen, V.; Kalliomaki, M.; Arkkila, P.; Satokari, R. Mucosal Prevalence and Interactions with the Epithelium Indicate Commensalism of Sutterella spp. Front. Microbiol. 2016, 7, 1706. [CrossRef]

149. Zhai, R.; Xue, X.; Zhang, L.; Yang, X.; Zhao, L.; Zhang, C. Strain-Specific Anti-inflammatory Properties of Two Akkermansia muciniphila Strains on Chronic Colitis in Mice. Front. Cell. Infect. Microbiol. 2019, 9, 239. [CrossRef]

150. Haran, J.P.; Bhattarai, S.K.; Foley, S.E.; Dutta, P.; Ward, D.V.; Bucci, V.; McCormick, B.A. Alzheimer's Disease Microbiome Is Associated with Dysregulation of the Anti-Inflammatory P-Glycoprotein Pathway. mBio 2019, 10. [CrossRef] [PubMed]

151. Sanchez, B.; Delgado, S.; Blanco-Miguez, A.; Lourenco, A.; Gueimonde, M.; Margolles, A. Probiotics, gut microbiota, and their influence on host health and disease. Mol. Nutr. Food Res. 2017, 61. [CrossRef] [PubMed]

152. Bonfili, L.; Cecarini, V.; Berardi, S.; Scarpona, S.; Suchodolski, J.S.; Nasuti, C.; Fiorini, D.; Boarelli, M.C.; Rossi, G.; Eleuteri, A.M. Microbiota modulation counteracts Alzheimer's disease progression influencing neuronal proteolysis and gut hormones plasma levels. Sci. Rep. 2017, 7, 2426. [CrossRef]

153. Abraham, D.; Feher, J.; Scuderi, G.L.; Szabo, D.; Dobolyi, A.; Cservenak, M.; Juhasz, J.; Ligeti, B.; Pongor, S.; Gomez-Cabrera, M.C.; et al. Exercise and probiotics attenuate the development of Alzheimer's disease in transgenic mice: Role of microbiome. Exp. Gerontol. 2019, 115, 122-131. [CrossRef] [PubMed]

154. Wang, M.; Amakye, W.K.; Guo, L.; Gong, C.; Zhao, Y.; Yao, M.; Ren, J. Walnut-Derived Peptide PW5 Ameliorates Cognitive Impairments and Alters Gut Microbiota in APP/PS1 Transgenic Mice. Mol. Nutr. Food Res. 2019, 63, e1900326. [CrossRef] [PubMed]

155. Kristensen, N.B.; Bryrup, T.; Allin, K.H.; Nielsen, T.; Hansen, T.H.; Pedersen, O. Alterations in fecal microbiota composition by probiotic supplementation in healthy adults: A systematic review of randomized controlled trials. Genome Med. $2016,8,52$. [CrossRef]

156. Shokryazdan, P.; Faseleh Jahromi, M.; Navidshad, B.; Liang, J.B. Effects of prebiotics on immune system and cytokine expression. Med. Microbiol. Immunol. 2017, 206, 1-9. [CrossRef]

157. Wahl, D.; Solon-Biet, S.M.; Wang, Q.P.; Wali, J.A.; Pulpitel, T.; Clark, X.; Raubenheimer, D.; Senior, A.M.; Sinclair, D.A.; Cooney, G.J.; et al. Comparing the Effects of Low-Protein and High-Carbohydrate Diets and Caloric Restriction on Brain Aging in Mice. Cell Rep. 2018, 25, 2234-2243. [CrossRef] [PubMed]

158. Mattson, M.P.; Moehl, K.; Ghena, N.; Schmaedick, M.; Cheng, A. Intermittent metabolic switching, neuroplasticity and brain health. Nat. Rev. Neurosci. 2018, 19, 63-80. [CrossRef] [PubMed]

159. Mattson, M.P.; Arumugam, T.V. Hallmarks of Brain Aging: Adaptive and Pathological Modification by Metabolic States. Cell Metab. 2018, 27, 1176-1199. [CrossRef] [PubMed]

160. de Cabo, R.; Mattson, M.P. Effects of Intermittent Fasting on Health, Aging, and Disease. N. Engl. J. Med. 2019, $381,2541-2551$. [CrossRef]

161. Nasaruddin, M.L.; Syed Abd Halim, S.A.; Kamaruzzaman, M.A. Studying the Relationship of Intermittent Fasting and betaAmyloid in Animal Model of Alzheimer's Disease: A Scoping Review. Nutrients 2020, 12, 3215. [CrossRef]

162. Wang, X.; Liu, Q.; Zhou, J.; Wu, X.; Zhu, Q. beta hydroxybutyrate levels in serum and cerebrospinal fluid under ketone body metabolism in rats. Exp. Anim. 2017, 66, 177-182. [CrossRef]

163. Li, X.; Zhan, Z.; Zhang, J.; Zhou, F.; An, L. beta-Hydroxybutyrate Ameliorates Abeta-Induced Downregulation of TrkA Expression by Inhibiting HDAC1/3 in SH-SY5Y Cells. Am. J. Alzheimer's Dis. Other Demen. 2020, 35, 1533317519883496. [CrossRef]

164. Xie, G.; Tian, W.; Wei, T.; Liu, F. The neuroprotective effects of beta-hydroxybutyrate on Abeta-injected rat hippocampus in vivo and in Abeta-treated PC-12 cells in vitro. Free Radic. Res. 2015, 49, 139-150. [CrossRef] [PubMed]

165. Hu, E.; Du, H.; Shang, S.; Zhang, Y.; Lu, X. Beta-Hydroxybutyrate Enhances BDNF Expression by Increasing H3K4me3 and Decreasing H2AK119ub in Hippocampal Neurons. Front. Neurosci. 2020, 14, 591177. [CrossRef] [PubMed] 
166. Dabke, P.; Das, A.M. Mechanism of Action of Ketogenic Diet Treatment: Impact of Decanoic Acid and Beta-Hydroxybutyrate on Sirtuins and Energy Metabolism in Hippocampal Murine Neurons. Nutrients 2020, 12, 2379. [CrossRef]

167. Lazic, D.; Tesic, V.; Jovanovic, M.; Brkic, M.; Milanovic, D.; Zlokovic, B.V.; Kanazir, S.; Perovic, M. Every-other-day feeding exacerbates inflammation and neuronal deficits in 5XFAD mouse model of Alzheimer's disease. Neurobiol. Dis. 2020, $136,104745$. [CrossRef]

168. Zhang, J.; Zhan, Z.; Li, X.; Xing, A.; Jiang, C.; Chen, Y.; Shi, W.; An, L. Intermittent Fasting Protects against Alzheimer's Disease Possible through Restoring Aquaporin-4 Polarity. Front. Mol. Neurosci. 2017, 10, 395. [CrossRef]

169. Liu, Y.; Cheng, A.; Li, Y.J.; Yang, Y.; Kishimoto, Y.; Zhang, S.; Wang, Y.; Wan, R.; Raefsky, S.M.; Lu, D.; et al. SIRT3 mediates hippocampal synaptic adaptations to intermittent fasting and ameliorates deficits in APP mutant mice. Nat. Commun. 2019, 10, 1886. [CrossRef]

170. Li, W.; Wu, M.; Zhang, Y.; Wei, X.; Zang, J.; Liu, Y.; Wang, Y.; Gong, C.X.; Wei, W. Intermittent fasting promotes adult hippocampal neuronal differentiation by activating GSK-3beta in 3xTg-AD mice. J. Neurochem. 2020. [CrossRef]

171. Kashiwaya, Y.; Bergman, C.; Lee, J.H.; Wan, R.; King, M.T.; Mughal, M.R.; Okun, E.; Clarke, K.; Mattson, M.P.; Veech, R.L. A ketone ester diet exhibits anxiolytic and cognition-sparing properties, and lessens amyloid and tau pathologies in a mouse model of Alzheimer's disease. Neurobiol. Aging 2013, 34, 1530-1539. [CrossRef]

172. Schnurr, T.M.; Jakupovic, H.; Carrasquilla, G.D.; Angquist, L.; Grarup, N.; Sorensen, T.I.A.; Tjonneland, A.; Overvad, K.; Pedersen, O.; Hansen, T.; et al. Obesity, unfavourable lifestyle and genetic risk of type 2 diabetes: A case-cohort study. Diabetologia 2020, 63, 1324-1332. [CrossRef]

173. Tremblay, J.; Hamet, P. Environmental and genetic contributions to diabetes. Metabolism 2019, 100S, 153952. [CrossRef]

174. Lindenberg, F.C.B.; Ellekilde, M.; Thorn, A.C.; Kihl, P.; Larsen, C.S.; Hansen, C.H.F.; Metzdorff, S.B.; Aalbaek, B.; Hansen, A.K. Dietary LPS traces influences disease expression of the diet-induced obese mouse. Res. Vet Sci. 2019, 123, 195-203. [CrossRef] [PubMed]

175. Bingxuan Wang, P.; Chandrasekera, C.; Pippin, J.J. Leptin- and Leptin Receptor-Deficient Rodent Models: Relevance for Human Type 2 Diabetes. Curr. Diabetes Rev. 2014, 10, 131-145. [CrossRef] [PubMed]

176. Avtanski, D.; Pavlov, V.A.; Tracey, K.J.; Poretsky, L. Characterization of inflammation and insulin resistance in high-fat dietinduced male C57BL/6J mouse model of obesity. Anim. Model. Exp. Med. 2019, 2, 252-258. [CrossRef]

177. Cao, Y.; Sun, Y.; Zou, S.; Duan, B.; Sun, M.; Xu, X. Yeast beta-Glucan Suppresses the Chronic Inflammation and Improves the Microenvironment in Adipose Tissues of ob/ob Mice. J Agric Food Chem 2018, 66, 621-629. [CrossRef] [PubMed]

178. Morris, J.L.; Bridson, T.L.; Alim, M.A.; Rush, C.M.; Rudd, D.M.; Govan, B.L.; Ketheesan, N. Development of a diet-induced murine model of diabetes featuring cardinal metabolic and pathophysiological abnormalities of type 2 diabetes. Biol. Open 2016, 5, 1149-1162. [CrossRef]

179. Preguica, I.; Alves, A.; Nunes, S.; Gomes, P.; Fernandes, R.; Viana, S.D.; Reis, F. Diet-Induced Rodent Models of Diabetic Peripheral Neuropathy, Retinopathy and Nephropathy. Nutrients 2020, 12, 250. [CrossRef]

180. Showalter, M.R.; Nonnecke, E.B.; Linderholm, A.L.; Cajka, T.; Sa, M.R.; Lonnerdal, B.; Kenyon, N.J.; Fiehn, O. Obesogenic diets alter metabolism in mice. PLoS ONE 2018, 13, e0190632. [CrossRef]

181. Rodriguez-Correa, E.; Gonzalez-Perez, I.; Clavel-Perez, P.I.; Contreras-Vargas, Y.; Carvajal, K. Biochemical and nutritional overview of diet-induced metabolic syndrome models in rats: What is the best choice? Nutr. Diabetes 2020, 10, 24. [CrossRef]

182. Gilani, A.; Pandey, V.; Garcia, V.; Agostinucci, K.; Singh, S.P.; Schragenheim, J.; Bellner, L.; Falck, J.R.; Paudyal, M.P.; Capdevila, J.H.; et al. High-fat diet-induced obesity and insulin resistance in CYP4a14(-/-) mice is mediated by 20-HETE. Am. J. Physiol. Regul. Integr. Comp. Physiol. 2018, 315, R934-R944. [CrossRef]

183. Rocha, V.D.S.; Claudio, E.R.G.; da Silva, V.L.; Cordeiro, J.P.; Domingos, L.F.; da Cunha, M.R.H.; Mauad, H.; do Nascimento, T.B.; Lima-Leopoldo, A.P.; Leopoldo, A.S. High-Fat Diet-Induced Obesity Model Does Not Promote Endothelial Dysfunction via Increasing Leptin/Akt/eNOS Signaling. Front. Physiol. 2019, 10, 268. [CrossRef]

184. Ussar, S.; Griffin, N.W.; Bezy, O.; Fujisaka, S.; Vienberg, S.; Softic, S.; Deng, L.; Bry, L.; Gordon, J.I.; Kahn, C.R. Interactions between Gut Microbiota, Host Genetics and Diet Modulate the Predisposition to Obesity and Metabolic Syndrome. Cell Metab. 2015, 22, 516-530. [CrossRef]

185. You-Hua, X.; Chen-Lin, G.; Heng-Li, G.; Wen-Qian, Z.; Wei Huang, S.-S.T.; Wen-Jun, G.; Yong, X.; Hua, Z.; Quan, Z. Sodium Butyrate Supplementation Ameliorates Diabetic Inflammation in db/db Mice. J. Endocrinol. 2018, 238, 231-244.

186. Burke, S.J.; Batdorf, H.M.; Burk, D.H.; Noland, R.C.; Eder, A.E.; Boulos, M.S.; Karlstad, M.D.; Collier, J.J. db/db Mice Exhibit Features of Human Type 2 Diabetes That Are Not Present in Weight-Matched C57BL/6J Mice Fed a Western Diet. J. Diabetes Res. 2017, 2017, 8503754. [CrossRef]

187. Dey, A.; Hao, S.; Erion, J.R.; Wosiski-Kuhn, M.; Stranahan, A.M. Glucocorticoid sensitization of microglia in a genetic mouse model of obesity and diabetes. J. Neuroimmunol. 2014, 269, 20-27. [CrossRef] [PubMed]

188. Zhang, W.; Xu, J.H.; Yu, T.; Chen, Q.K. Effects of berberine and metformin on intestinal inflammation and gut microbiome composition in db/db mice. Biomed. Pharm. 2019, 118, 109131. [CrossRef] [PubMed]

189. Cui, S.; Qiao, L.; Yu, S.; Men, L.; Li, Y.; Li, F.; Du, J. The Antagonist of CXCR1 and CXCR2Protects db/db mice from Metabolic Diseasesthrough Modulating Inflammation. Am. J. Physiol. Endocrinol. Metab. 2019, 317, E1205-E1217. [CrossRef] [PubMed] 
190. Petersen, C.; Bharat, D.; Cutler, B.R.; Gholami, S.; Denetso, C.; Mueller, J.E.; Cho, J.M.; Kim, J.S.; Symons, J.D.; Anandh Babu, P.V. Circulating metabolites of strawberry mediate reductions in vascular inflammation and endothelial dysfunction in $\mathrm{db} / \mathrm{db}$ mice. Int. J. Cardiol. 2018, 263, 111-117. [CrossRef]

191. Steven, S.; Dib, M.; Hausding, M.; Kashani, F.; Oelze, M.; Kröller-Schön, S.; Hanf, A.; Daub, S.; Roohani, S.; Gramlich, Y.; et al. CD40L controls obesity-associated vascular inflammation, oxidative stress, and endothelial dysfunction in high fat diet-treated and $\mathrm{db} / \mathrm{db}$ mice. Cardiovasc. Res. 2018, 114, 312-323. [CrossRef]

192. Mracek, T.; Gao, D.; Tzanavari, T.; Bao, Y.; Xiao, X.; Stocker, C.; Trayhurn, P.; Bing, C. Downregulation of zinc-\{alpha\}2glycoprotein in adipose tissue and liver of obese ob/ob mice and by tumour necrosis factor-alpha in adipocytes. J. Endocrinol. 2010, 204, 165-172. [CrossRef]

193. Sutter, A.G.; Palanisamy, A.P.; Lench, J.H.; Jessmore, A.P.; Chavin, K.D. Development of steatohepatitis in Ob/Ob mice is dependent on Toll-like receptor 4. Ann. Hepatol. 2015, 14, 735-743. [CrossRef]

194. Ye, C.; Wang, R.; Wang, M.; Huang, Z.; Tang, C. Leptin alleviates intestinal mucosal barrier injury and inflammation in obese mice with acute pancreatitis. Int. J. Obes. 2018, 42, 1471-1479. [CrossRef] [PubMed]

195. Sartori, M.; Conti, F.F.; Dias, D.D.S.; Dos Santos, F.; Machi, J.F.; Palomino, Z.; Casarini, D.E.; Rodrigues, B.; De Angelis, K.; Irigoyen, M.C. Association between Diastolic Dysfunction with Inflammation and Oxidative Stress in Females ob/ob Mice. Front. Physiol. 2017, 8, 572. [CrossRef] [PubMed]

196. Son, M.; Oh, S.; Choi, J.; Jang, J.T.; Choi, C.H.; Park, K.Y.; Son, K.H.; Byun, K. Attenuation of Inflammation and Leptin Resistance by Pyrogallol-Phloroglucinol-6,6-Bieckol on in the Brain of Obese Animal Models. Nutrients 2019, 11, 2773. [CrossRef]

197. Zheng, W.; Zhou, J.; Song, S.; Kong, W.; Xia, W.; Chen, L.; Zeng, T. Dipeptidyl-Peptidase 4 Inhibitor Sitagliptin Ameliorates Hepatic Insulin Resistance by Modulating Inflammation and Autophagy in ob/ob Mice. Int. J. Endocrinol. 2018, $2018,8309723$. [CrossRef] [PubMed]

198. Cani, P.D.; Possemiers, S.; Van de Wiele, T.; Guiot, Y.; Everard, A.; Rottier, O.; Geurts, L.; Naslain, D.; Neyrinck, A.; Lambert, D.M.; et al. Changes in gut microbiota control inflammation in obese mice through a mechanism involving GLP-2-driven improvement of gut permeability. Gut 2009, 58, 1091-1103. [CrossRef]

199. Jena, P.K.; Sheng, L.; Di Lucente, J.; Jin, L.W.; Maezawa, I.; Wan, Y.Y. Dysregulated bile acid synthesis and dysbiosis are implicated in Western diet-induced systemic inflammation, microglial activation, and reduced neuroplasticity. FASEB J. 2018, 32, $2866-2877$. [CrossRef] [PubMed]

200. Heijden, R.A.v.d.; Sheedfar, F.; Morrison, M.C.; Hommelberg, P.P.; Kor, D.; Kloosterhuis, N.J.; Gruben, N.; Youssef, S.A.; Bruin, A.D.; Hofker, M.H.; et al. High-fat diet induced obesity primes inflammation in adipose tissue prior to liver in C57BL/6j mice. Aging 2015, 7, 256-267. [CrossRef]

201. He, M.Q.; Wang, J.Y.; Wang, Y.; Sui, J.; Zhang, M.; Ding, X.; Zhao, Y.; Chen, Z.Y.; Ren, X.X.; Shi, B.Y. High-fat diet-induced adipose tissue expansion occurs prior to insulin resistance in C57BL/6J mice. Chronic Dis. Transl. Med. 2020, 6, 198-207. [CrossRef] [PubMed]

202. Tsuru, H.; Osaka, M.; Hiraoka, Y.; Yoshida, M. HFD-induced hepatic lipid accumulation and inflammation are decreased in Factor D deficient mouse. Sci. Rep. 2020, 10, 17593. [CrossRef]

203. Schroeder, B.O.; Birchenough, G.M.H.; Pradhan, M.; Nystrom, E.E.L.; Henricsson, M.; Hansson, G.C.; Backhed, F. Obesityassociated microbiota contributes to mucus layer defects in genetically obese mice. J. Biol. Chem. 2020. [CrossRef]

204. Singh, H.; Miyamoto, S.; Darshi, M.; Torralba, M.G.; Kwon, K.; Sharma, K.; Pieper, R. Gut Microbial Changes in Diabetic db/db Mice and Recovery of Microbial Diversity upon Pirfenidone Treatment. Microorganisms 2020, 8, 1347. [CrossRef] [PubMed]

205. Cao, Y.; Yao, G.; Sheng, Y.; Yang, L.; Wang, Z.; Yang, Z.; Zhuang, P.; Zhang, Y. JinQi Jiangtang Tablet Regulates Gut Microbiota and Improve Insulin Sensitivity in Type 2 Diabetes Mice. J. Diabetes Res. 2019, 2019, 1872134. [CrossRef]

206. Nagpal, R.; Mishra, S.P.; Yadav, H. Unique Gut Microbiome Signatures Depict Diet-Versus Genetically Induced Obesity in Mice. Int. J. Mol. Sci. 2020, 21, 3434. [CrossRef]

207. Liu, Z.; Dai, X.; Zhang, H.; Shi, R.; Hui, Y.; Jin, X.; Zhang, W.; Wang, L.; Wang, Q.; Wang, D.; et al. Gut microbiota mediates intermittent-fasting alleviation of diabetes-induced cognitive impairment. Nat. Commun. 2020, 11, 855. [CrossRef] [PubMed]

208. Wei, Z.; Shen, P.; Cheng, P.; Lu, Y.; Wang, A.; Sun, Z. Gut Bacteria Selectively Altered by Sennoside a Alleviate Type 2 Diabetes and Obesity Traits. Oxid. Med. Cell. Longev. 2020, 2020, 2375676. [CrossRef]

209. Deng, N.; He, Z.; Guo, R.; Zheng, B.; Li, T.; Liu, R.H. Highland Barley Whole Grain (Hordeum vulgare L.) Ameliorates Hyperlipidemia by Modulating Cecal Microbiota, miRNAs, and AMPK Pathways in Leptin Receptor-Deficient db/db Mice. J. Agric. Food Chem. 2020, 68, 11735-11746. [CrossRef] [PubMed]

210. Cai, T.T.; Ye, X.L.; Li, R.R.; Chen, H.; Wang, Y.Y.; Yong, H.J.; Pan, M.L.; Lu, W.; Tang, Y.; Miao, H.; et al. Resveratrol Modulates the Gut Microbiota and Inflammation to Protect against Diabetic Nephropathy in Mice. Front. Pharm. 2020, 11, 1249. [CrossRef] [PubMed]

211. Chen, Q.; Ren, D.; Wu, J.; Yu, H.; Chen, X.; Wang, J.; Zhang, Y.; Liu, M.; Wang, T. Shenyan Kangfu tablet alleviates diabetic kidney disease through attenuating inflammation and modulating the gut microbiota. J. Nat. Med. 2020. [CrossRef]

212. Yu, F.; Han, W.; Zhan, G.; Li, S.; Xiang, S.; Zhu, B.; Jiang, X.; Yang, L.; Luo, A.; Hua, F.; et al. Abnormal gut microbiota composition contributes to cognitive dysfunction in streptozotocin-induced diabetic mice. Aging (Albany N.Y.) 2019, 11, 3262-3279. [CrossRef] 
213. Bagarolli, R.A.; Tobar, N.; Oliveira, A.G.; Araujo, T.G.; Carvalho, B.M.; Rocha, G.Z.; Vecina, J.F.; Calisto, K.; Guadagnini, D.; Prada, P.O.; et al. Probiotics modulate gut microbiota and improve insulin sensitivity in DIO mice. J. Nutr. Biochem. 2017, 50, 16-25. [CrossRef]

214. Kocsis, T.; Molnar, B.; Nemeth, D.; Hegyi, P.; Szakacs, Z.; Balint, A.; Garami, A.; Soos, A.; Marta, K.; Solymar, M. Probiotics have beneficial metabolic effects in patients with type 2 diabetes mellitus: A meta-analysis of randomized clinical trials. Sci. Rep. 2020, 10, 11787. [CrossRef]

215. Di Renzo, L.; Gualtieri, P.; Romano, L.; Marrone, G.; Noce, A.; Pujia, A.; Perrone, M.A.; Aiello, V.; Colica, C.; De Lorenzo, A. Role of Personalized Nutrition in Chronic-Degenerative Diseases. Nutrients 2019, 11, 1707. [CrossRef] [PubMed]

216. Liu, Z.; Yuan, T.; Dai, X.; Shi, L.; Liu, X. Intermittent Fasting Alleviates Diabetes-induced Cognitive Decline via Gut Microbiotametabolites-brain Axis (OR32-04-19). Curr. Dev. Nutr. 2019, 3. [CrossRef]

217. Chen, C.; You, L.J.; Huang, Q.; Fu, X.; Zhang, B.; Liu, R.H.; Li, C. Modulation of gut microbiota by mulberry fruit polysaccharide treatment of obese diabetic $\mathrm{db} / \mathrm{db}$ mice. Food Funct. 2018, 9, 3732-3742. [CrossRef] [PubMed]

218. Xie, Y.; Xiao, M.; Ni, Y.; Jiang, S.; Feng, G.; Sang, S.; Du, G. Alpinia oxyphylla Miq. Extract Prevents Diabetes in Mice by Modulating Gut Microbiota. J. Diabetes Res. 2018, 2018, 4230590. [CrossRef] [PubMed]

219. Ju, M.; Liu, Y.; Li, M.; Cheng, M.; Zhang, Y.; Deng, G.; Kang, X.; Liu, H. Baicalin improves intestinal microecology and abnormal metabolism induced by high-fat diet. Eur. J. Pharm. 2019, 857, 172457. [CrossRef] [PubMed]

220. Beli, E.; Yan, Y.; Moldovan, L.; Vieira, C.P.; Gao, R.; Duan, Y.; Prasad, R.; Bhatwadekar, A.; White, F.A.; Townsend, S.D.; et al Restructuring of the Gut Microbiome by Intermittent Fasting Prevents Retinopathy and Prolongs Survival in db/db Mice. Diabetes 2018, 67, 1867-1879. [CrossRef]

221. Biessels, G.J.; Despa, F. Cognitive decline and dementia in diabetes mellitus: Mechanisms and clinical implications. Nat. Rev. Endocrinol. 2018, 14, 591-604. [CrossRef]

222. Craft, S. The role of metabolic disorders in Alzheimer disease and vascular dementia: Two roads converged. Arch. Neurol. 2009, 66, 300-305. [CrossRef]

223. Moyse, E.; Haddad, M.; Benlabiod, C.; Ramassamy, C.; Krantic, S. Common Pathological Mechanisms and Risk Factors for Alzheimer's Disease and Type-2 Diabetes: Focus on Inflammation. Curr. Alzheimer Res. 2019, 16, 986-1006. [CrossRef]

224. Salas, I.H.; De Strooper, B. Diabetes and Alzheimer's Disease: A Link not as Simple as it Seems. Neurochem. Res. 2019, 44, 1271-1278. [CrossRef]

225. Davari, S.; Talaei, S.A.; Alaei, H.; Salami, M. Probiotics treatment improves diabetes-induced impairment of synaptic activity and cognitive function: Behavioral and electrophysiological proofs for microbiome-gut-brain axis. Neuroscience 2013, 240, 287-296. [CrossRef] [PubMed]

226. Gao, K.; Yang, R.; Zhang, J.; Wang, Z.; Jia, C.; Zhang, F.; Li, S.; Wang, J.; Murtaza, G.; Xie, H.; et al. Effects of Qijian mixture on type 2 diabetes assessed by metabonomics, gut microbiota and network pharmacology. Pharm. Res. 2018, 130, 93-109. [CrossRef] [PubMed]

227. Miklossy, J.; McGeer, P.L. Common mechanisms involved in Alzheimer's disease and type 2 diabetes: A key role of chronic bacterial infection and inflammation. Aging 2016, 8, 575-588. [CrossRef] [PubMed]

228. Agusti, A.; Garcia-Pardo, M.P.; Lopez-Almela, I.; Campillo, I.; Maes, M.; Romani-Perez, M.; Sanz, Y. Interplay Between the Gut-Brain Axis, Obesity and Cognitive Function. Front. Neurosci. 2018, 12, 155. [CrossRef] [PubMed]

229. Naseer, M.I.; Bibi, F.; Alqahtani, M.H.; Chaudhary, A.G.; Azhar, E.I.; Kamal, M.A.; Yasir, M. Role of gut microbiota in obesity, type 2 diabetes and Alzheimer's disease. CNS Neurol. Disord. Drug Targets 2014, 13, 305-311. [CrossRef] [PubMed]

230. Chan, E.S.; Chen, C.; Soong, T.W.; Wong, B.S. Differential Binding of Human ApoE Isoforms to Insulin Receptor is Associated with Aberrant Insulin Signaling in AD Brain Samples. Neuromol. Med. 2018, 20, 124-132. [CrossRef]

231. Levy, O.; Lavalette, S.; Hu, S.J.; Housset, M.; Raoul, W.; Eandi, C.; Sahel, J.A.; Sullivan, P.M.; Guillonneau, X.; Sennlaub, F. APOE Isoforms Control Pathogenic Subretinal Inflammation in Age-Related Macular Degeneration. J. Neurosci. 2015, 35, 13568-13576. [CrossRef]

232. Soto, I.; Graham, L.C.; Richter, H.J.; Simeone, S.N.; Radell, J.E.; Grabowska, W.; Funkhouser, W.K.; Howell, M.C.; Howell, G.R. APOE Stabilization by Exercise Prevents Aging Neurovascular Dysfunction and Complement Induction. PLoS Biol. 2015, 13, e1002279. [CrossRef]

233. Zhao, N.; Liu, C.C.; Van Ingelgom, A.J.; Martens, Y.A.; Linares, C.; Knight, J.A.; Painter, M.M.; Sullivan, P.M.; Bu, G. Apolipoprotein E4 Impairs Neuronal Insulin Signaling by Trapping Insulin Receptor in the Endosomes. Neuron 2017, 96, 115-129.e115. [CrossRef] [PubMed]

234. Youmans, K.L.; Tai, L.M.; Nwabuisi-Heath, E.; Jungbauer, L.; Kanekiyo, T.; Gan, M.; Kim, J.; Eimer, W.A.; Estus, S.; Rebeck, G.W.; et al. APOE4-specific changes in Abeta accumulation in a new transgenic mouse model of Alzheimer disease. J. Biol. Chem. 2012, 287, 41774-41786. [CrossRef] [PubMed]

235. Yuan, T.; Chu, C.; Shi, R.; Cui, T.; Zhang, X.; Zhao, Y.; Shi, X.; Hui, Y.; Pan, J.; Qian, R.; et al. ApoE-Dependent Protective Effects of Sesamol on High-Fat Diet-Induced Behavioral Disorders: Regulation of the Microbiome-Gut-Brain Axis. J. Agric. Food Chem. 2019, 67, 6190-6201. [CrossRef]

236. Kothari, V.; Luo, Y.; Tornabene, T.; O’Neill, A.M.; Greene, M.W.; Geetha, T.; Babu, J.R. High fat diet induces brain insulin resistance and cognitive impairment in mice. Biochim. Biophys. Acta Mol. Basis Dis. 2017, 1863, 499-508. [CrossRef] [PubMed] 
237. Janssen, C.I.; Jansen, D.; Mutsaers, M.P.; Dederen, P.J.; Geenen, B.; Mulder, M.T.; Kiliaan, A.J. The Effect of a High-Fat Diet on Brain Plasticity, Inflammation and Cognition in Female ApoE4-Knockin and ApoE-Knockout Mice. PLoS ONE 2016, 11, e0155307. [CrossRef]

238. Theriault, P.; ElAli, A.; Rivest, S. High fat diet exacerbates Alzheimer's disease-related pathology in APPswe/PS1 mice. Oncotarget 2016, 7, 67808-67827. [CrossRef]

239. Medrano-Jimenez, E.; Jimenez-Ferrer Carrillo, I.; Pedraza-Escalona, M.; Ramirez-Serrano, C.E.; Alvarez-Arellano, L.; Cortes-Mendoza, J.; Herrera-Ruiz, M.; Jimenez-Ferrer, E.; Zamilpa, A.; Tortoriello, J.; et al. Malva parviflora extract ameliorates the deleterious effects of a high fat diet on the cognitive deficit in a mouse model of Alzheimer's disease by restoring microglial function via a PPAR-gamma-dependent mechanism. J. Neuroinflamm. 2019, 16, 143. [CrossRef]

240. Matsuda, T.; Hisatsune, T. Cholinergic Modification of Neurogenesis and Gliosis Improves the Memory of AbetaPPswe/PSEN1dE9 Alzheimer's Disease Model Mice Fed a High-Fat Diet. J. Alzheimer's Dis. 2017, 56, 1-23. [CrossRef]

241. Ramos-Rodriguez, J.J.; Spires-Jones, T.; Pooler, A.M.; Lechuga-Sancho, A.M.; Bacskai, B.J.; Garcia-Alloza, M. Progressive Neuronal Pathology and Synaptic Loss Induced by Prediabetes and Type 2 Diabetes in a Mouse Model of Alzheimer's Disease. Mol. Neurobiol. 2017, 54, 3428-3438. [CrossRef] [PubMed]

242. Nakandakari, S.; Munoz, V.R.; Kuga, G.K.; Gaspar, R.C.; Sant'Ana, M.R.; Pavan, I.C.B.; da Silva, L.G.S.; Morelli, A.P.; Simabuco, F.M.; da Silva, A.S.R.; et al. Short-term high-fat diet modulates several inflammatory, ER stress, and apoptosis markers in the hippocampus of young mice. Brain Behav. Immun. 2019, 79, 284-293. [CrossRef] [PubMed]

243. Sah, S.K.; Lee, C.; Jang, J.H.; Park, G.H. Effect of high-fat diet on cognitive impairment in triple-transgenic mice model of Alzheimer's disease. Biochem. Biophys. Res. Commun. 2017, 493, 731-736. [CrossRef]

244. Fang, F.; Lue, L.F.; Yan, S.; Xu, H.; Luddy, J.S.; Chen, D.; Walker, D.G.; Stern, D.M.; Yan, S.; Schmidt, A.M.; et al. RAGE-dependent signaling in microglia contributes to neuroinflammation, Abeta accumulation, and impaired learning/memory in a mouse model of Alzheimer's disease. FASEB J. 2010, 24, 1043-1055. [CrossRef] [PubMed]

245. Valente, T.; Gella, A.; Fernandez-Busquets, X.; Unzeta, M.; Durany, N. Immunohistochemical analysis of human brain suggests pathological synergism of Alzheimer's disease and diabetes mellitus. Neurobiol. Dis. 2010, 37, 67-76. [CrossRef] [PubMed]

246. Knight, E.M.; Martins, I.V.; Gumusgoz, S.; Allan, S.M.; Lawrence, C.B. High-fat diet-induced memory impairment in tripletransgenic Alzheimer's disease (3xTgAD) mice is independent of changes in amyloid and tau pathology. Neurobiol. Aging 2014, 35, 1821-1832. [CrossRef]

247. Olgiati, P.; Politis, A.; Malitas, P.; Albani, D.; Dusi, S.; Polito, L.; De Mauro, S.; Zisaki, A.; Piperi, C.; Stamouli, E.; et al. APOE epsilon-4 allele and cytokine production in Alzheimer's disease. Int. J. Geriatr. Psychiatry 2010, 25, 338-344. [CrossRef]

248. Hoffman, J.D.; Yanckello, L.M.; Chlipala, G.; Hammond, T.C.; McCulloch, S.D.; Parikh, I.; Sun, S.; Morganti, J.M.; Green, S.J.; Lin, A.L. Dietary inulin alters the gut microbiome, enhances systemic metabolism and reduces neuroinflammation in an APOE4 mouse model. PLoS ONE 2019, 14, e221828. [CrossRef]

249. Gale, S.C.; Gao, L.; Mikacenic, C.; Coyle, S.M.; Rafaels, N.; Murray Dudenkov, T.; Madenspacher, J.H.; Draper, D.W.; Ge, W.; Aloor, J.J.; et al. APOepsilon4 is associated with enhanced in vivo innate immune responses in human subjects. J. Allergy Clin. Immunol. 2014, 134, 127-134. [CrossRef]

250. Parikh, I.J.; Estus, J.L.; Zajac, D.J.; Malik, M.; Maldonado Weng, J.; Tai, L.M.; Chlipala, G.E.; LaDu, M.J.; Green, S.J.; Estus, S. Murine Gut Microbiome Association with APOE Alleles. Front. Immunol. 2020, 11, 200. [CrossRef]

251. Vitek, M.P.; Brown, C.M.; Colton, C.A. APOE genotype-specific differences in the innate immune response. Neurobiol. Aging 2009, 30, 1350-1360. [CrossRef] [PubMed]

252. Bruce-Keller, A.J.; Fernandez-Kim, S.O.; Townsend, R.L.; Kruger, C.; Carmouche, R.; Newman, S.; Salbaum, J.M.; Berthoud, H.R. Maternal obese-type gut microbiota differentially impact cognition, anxiety and compulsive behavior in male and female offspring in mice. PLoS ONE 2017, 12, e0175577. [CrossRef] [PubMed]

253. Kowalski, K.; Mulak, A. Brain-Gut-Microbiota Axis in Alzheimer's Disease. J. Neurogastroenterol. Motil. 2019, 25, 48-60. [CrossRef] [PubMed]

254. Hwangbo, D.S.; Lee, H.Y.; Abozaid, L.S.; Min, K.J. Mechanisms of Lifespan Regulation by Calorie Restriction and Intermittent Fasting in Model Organisms. Nutrients 2020, 12, 1194. [CrossRef]

255. Sohal, R.S.; Forster, M.J. Caloric restriction and the aging process: A critique. Free Radic. Biol. Med. 2014, 73, 366-382. [CrossRef]

256. Zhang, C.; Li, S.; Yang, L.; Huang, P.; Li, W.; Wang, S.; Zhao, G.; Zhang, M.; Pang, X.; Yan, Z.; et al. Structural modulation of gut microbiota in life-long calorie-restricted mice. Nat. Commun. 2013, 4, 2163. [CrossRef]

257. Liu, C.; Zhou, N.; Du, M.X.; Sun, Y.T.; Wang, K.; Wang, Y.J.; Li, D.H.; Yu, H.Y.; Song, Y.; Bai, B.B.; et al. The Mouse Gut Microbial Biobank expands the coverage of cultured bacteria. Nat. Commun. 2020, 11, 79. [CrossRef]

258. Li, K.; Zhang, L.; Xue, J.; Yang, X.; Dong, X.; Sha, L.; Lei, H.; Zhang, X.; Zhu, L.; Wang, Z.; et al. Dietary inulin alleviates diverse stages of type 2 diabetes mellitus via anti-inflammation and modulating gut microbiota in db/db mice. Food Funct. 2019, 10, 1915-1927. [CrossRef] 